\title{
Article
}

http://dx.doi.org/10.11646/phytotaxa.219.1.1

\section{Taxonomic notes on the Acanthopsis disperma-hoffmannseggiana complex (Acanthaceae, tribe Acantheae), with an interim key to members of the genus}

\author{
HESTER M. STEYN ${ }^{1,2^{*}} \&$ ABRAHAM E. VAN WYK ${ }^{2}$ \\ ${ }^{I}$ National Herbarium, South African National Biodiversity Institute, Private Bag X101, Pretoria 0001, South Africa. \\ ${ }^{2}$ H.G.W.J. Schweickerdt Herbarium, Department of Plant Science, University of Pretoria, Pretoria 0002, South Africa. \\ *Author for correspondence.E-mail: h.steyn@sanbi.org.za
}

\begin{abstract}
Acanthopsis is a taxonomically poorly understood genus confined to arid parts of southern Africa. This contribution is the first detailed assessment of the diversity within the Acanthopsis disperma-hoffmannseggiana complex, the latter of which comprises the bulk of the specimens of the genus represented in herbaria. Species concepts are resolved and the misapplication of names is noted. In addition to the recognition of A. disperma and A. hoffmannseggiana, five new species of Acanthopsis formerly treated under these two names, are described, namely A. tuba and A. ludoviciana (both confined to the Richtersveld, Northern Cape, South Africa), A. adamanticola (endemic to southern Namibia), A. villosa (endemic to Bushmanland, Northern Cape) and A. dispermoides (endemic to the Western Cape, South Africa). The names $A$. disperma and $A$. hoffmannseggiana are lectotypified here. An identification key to the members of the Acanthopsis disperma-hoffmannseggiana complex is provided, as well as an interim key to the major artificial groupings in the genus, the taxonomy of some which still needs to be resolved.
\end{abstract}

Key words: Acanthodium, Acanthus, Blepharis, Gariep Centre of Endemism, Klein Karoo Centre of Endemism, Namibia, South Africa

\section{Introduction}

Acanthopsis Harvey (1842: 28) is a distinct and easily recognizable genus confined to arid parts of southern Africa. With the exception of Blepharis Jussieu (1789: 103), it is unlikely to be confused with any other genus of Acanthaceae native to the subcontinent. A member of the tribe Acantheae, Acanthopsis is a monophyletic group belonging to the socalled "one-lipped corolla lineage", the latter which comprises six clades of Old World taxa (McDade et al. 2005). The phylogenetic relationship among Acanthopsis, Acanthus (Linneaus 1753: 639) and Blepharis is not yet fully resolved, but available molecular evidence suggests that Acanthopsis and Acanthus are sister taxa (McDade et al. 2005).

Morphologically, Acanthopsis can be distinguished from other members of the Acanthaceae by a combination of four characters, namely a one-lipped corolla, spinous bracts terminating in 3-5 simple or compound spines (lobes), outer stamen filaments without an appendage at the tip, and a simple, unbranched filiform style with a single-lobed stigma. In contrast, all southern African representatives of Blepharis have outer stamen filaments with an appendage at the tip, and a bilobed stigma (Vollesen 2000).

Although superficially rather similar-looking, members of Acanthopsis display intricate patterns of variation and the infrageneric classification of the group is far from clear. Depending on the authority, eight (Welman 2003) or seven (Balkwill 2012) species have been recognized in recent years, all of which are confined to Namibia and South Africa. However, in the absence of a reliable key and well-defined diagnostic characters, identification of species has been an almost impossible task. The last complete genus account and only available identification key to members of Acanthopsis have been the one by Clarke (1901), now largely outdated. The present contribution emanates from an on-going taxonomic revision of the group by one of us (HMS) initiated in 2011.

Harvey (1842) established the genus Acanthopsis with, as the type species the nomen nudum Acanthodium dispermum E.Meyer in Drège (1837: 2), the latter name based on an annotated specimen in the herbarium of Jean François (Johann Franz) Drège [1794-1881]. Although Harvey (1842) referred to E. Meyer's name, he did not 
definitely associate the epithet "disperma" with the name of the new genus (refer to Art. 35.2 of the ICN; McNeill et al. 2012), and the name Acanthopsis disperma Nees in Candolle (1847: 278) was only validly published in 1847.

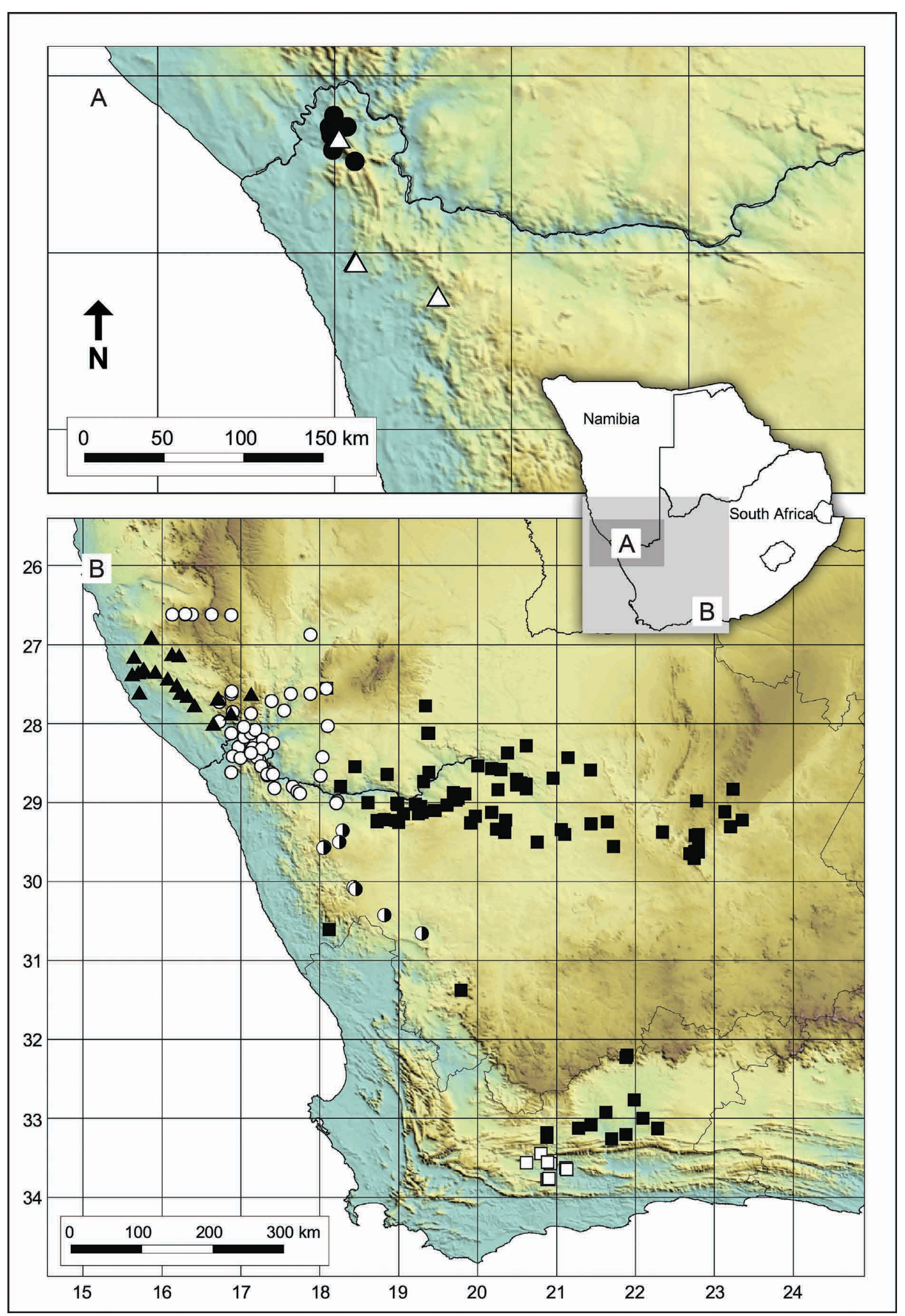

FIGURE 1. Known distribution of species within the Acanthopsis disperma-hoffmannseggiana complex. A: A. ludoviciana (•) and A.

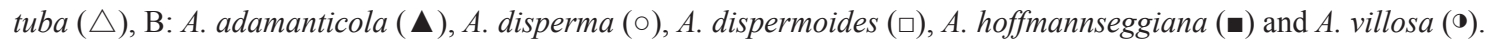



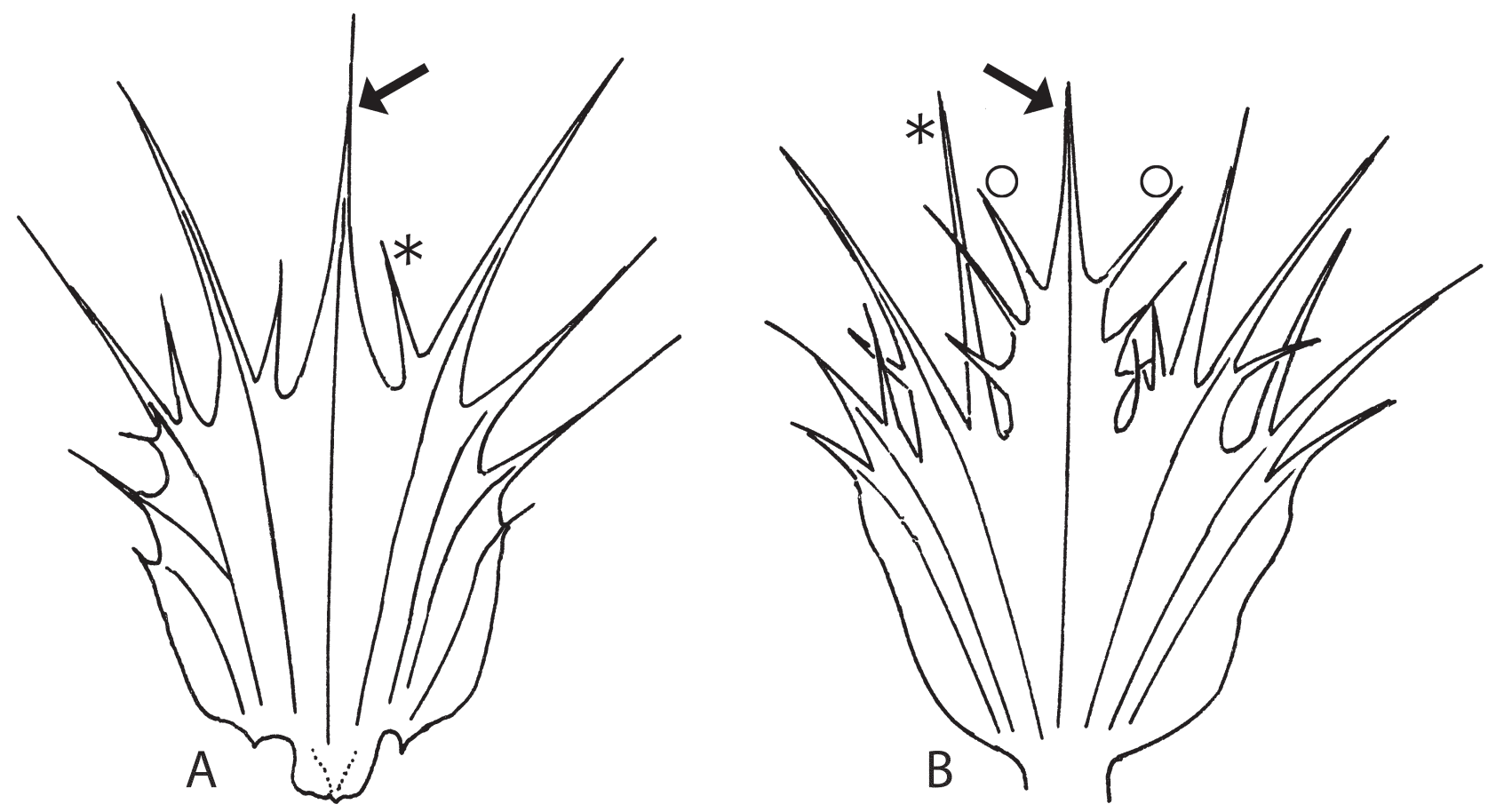

FIGURE 2. Floral bracts illustrating the terminology used. Examples are marked of basal secondary spines $(*)$ and marginal secondary spines $\left({ }^{\circ}\right)$. A. Bract with simple central primary spine (arrowed). B. Bract with compound central primary spine (arrowed). See text for more details. Artist: Gillian Condy.

Nees in Candolle (1847) described Acanthopsis disperma as "herbaceous, \pm stemless, with all leaves radical, lanceolate, narrowed at the base, repand-dentate, spinose-ciliate, with an oval, sessile spike with bracts upwards broader, palmate-multifid, with spinose lobes. Perennial?..." (translated from the original Latin by O.A. Leistner, pers. comm. 2010). Nees maintained both Acanthopsis and Acanthodium Delile (1813:241) and in the same contribution, he described another stemless (rosulate) species in the genus Acanthodium, namely Acanthodium hoffmannseggianum Nees in Candolle (1847: 277). It was described as "stemless, velvety-pubescent, with lanceolate leaves spinosely sinuate-dentate, spike subsessile...with bracts obovate-cuneate, palmately 5 -fid, lobes prickly spiny pinnatifid. Perennial." (translated from the original Latin by O.A. Leistner, pers. comm. 2010). Clarke (1901) moved Acanthodium hoffmannseggianum into the genus Acanthopsis stating that the main difference between these two species lies in the bract indumentum: bracts with white hairs, not viscid (Acanthopsis disperma) versus bracts with viscid, gland-tipped hairs (Acanthopsis hoffmannseggiana (Nees) C.B.Clarke (1901: 35)). However, from the available literature (Harvey 1842; Nees in Candolle 1847) it is not at all clear what the distinction between these two genera was meant to be. Today most of the species originally attributed to Acanthodium, is placed in Blepharis.

Members of the Acanthopsis disperma-hoffmannseggiana species complex range from southern Namibia to the Western Cape, South Africa (Fig. 1) and include the most frequently seen and collected entities within the genus. With the growing number of herbarium specimens of Acanthopsis over the years, there has been considerable confusion regarding the delimitation of both $A$. disperma and $A$. hoffmannseggiana. Currently (accessed 20 January 2015) over $50 \%$ of the 270 Acanthopsis specimens on the South African National Biodiversity Institute's BRAHMS database are named $A$. disperma, while $12 \%$ are identified as $A$. hoffmannseggiana. However, when these herbarium specimens were critically studied, it became clear that in particular the name $A$. disperma has been indiscriminately applied to a morphologically heterogeneous assemblage of specimens with, amongst other characters, different life cycles (annual vs. perennial), flower colour and leaf and bract characters.

An anonymous note on the species cover of Acanthopsis hoffmannseggiana in the National Herbarium (PRE) states: "I think these two [A. disperma and A. hoffmannseggiana] are synonyms although P.G. Meyer keeps them separate... There are intermediates which link A. disperma and A. hoffmannseggiana." Meyer (1961) noted that a distinctly intermediate form occurs in the Hay Division (Northern Cape, South Africa). Specimens from the KenhardtPofadder area in the Northern Cape are especially difficulty to assign to one of these two species.

The principal aims of this contribution are to highlight the diversity within the Acanthopsis dispermahoffmannseggiana species complex and to resolve its infrageneric taxonomy. Towards this end, species concepts are 
clarified, misapplication of names over decades are highlighted and, in addition to $A$. disperma and $A$. hoffmannseggiana, five new species are described which would simplify the identification of entities in this relative large, though artificial, group within the genus. The rest of the genus still include other species complexes that would need more study (and time) to resolve, but these are usually represented by relatively few herbarium specimens and include rarely encountered forms. For convenience, an interim key to major groupings (artificial) within the genus is supplied to at least enable identification of the species comprising the commonly encountered A. disperma-hoffmannseggiana complex.

A
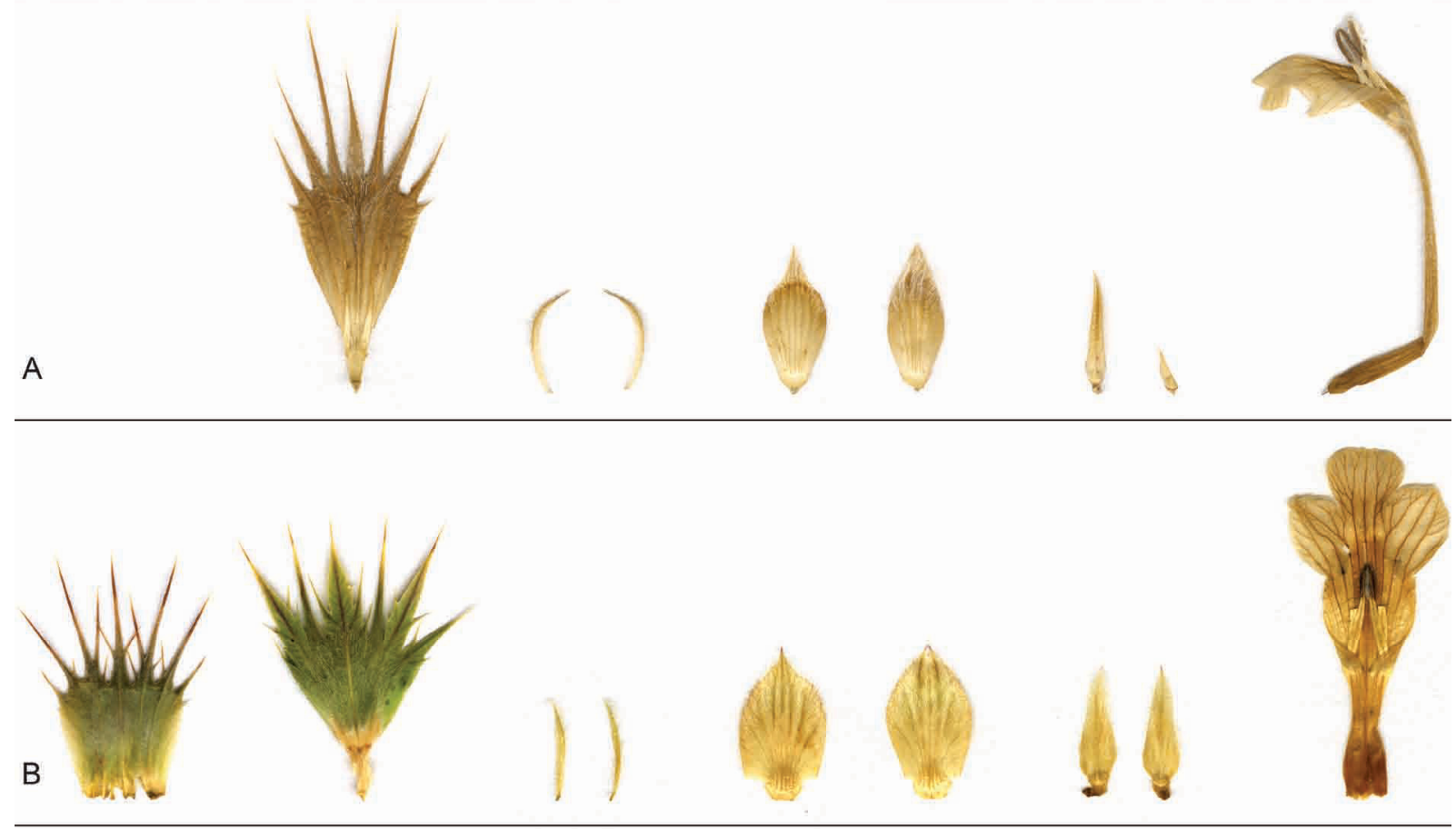

C
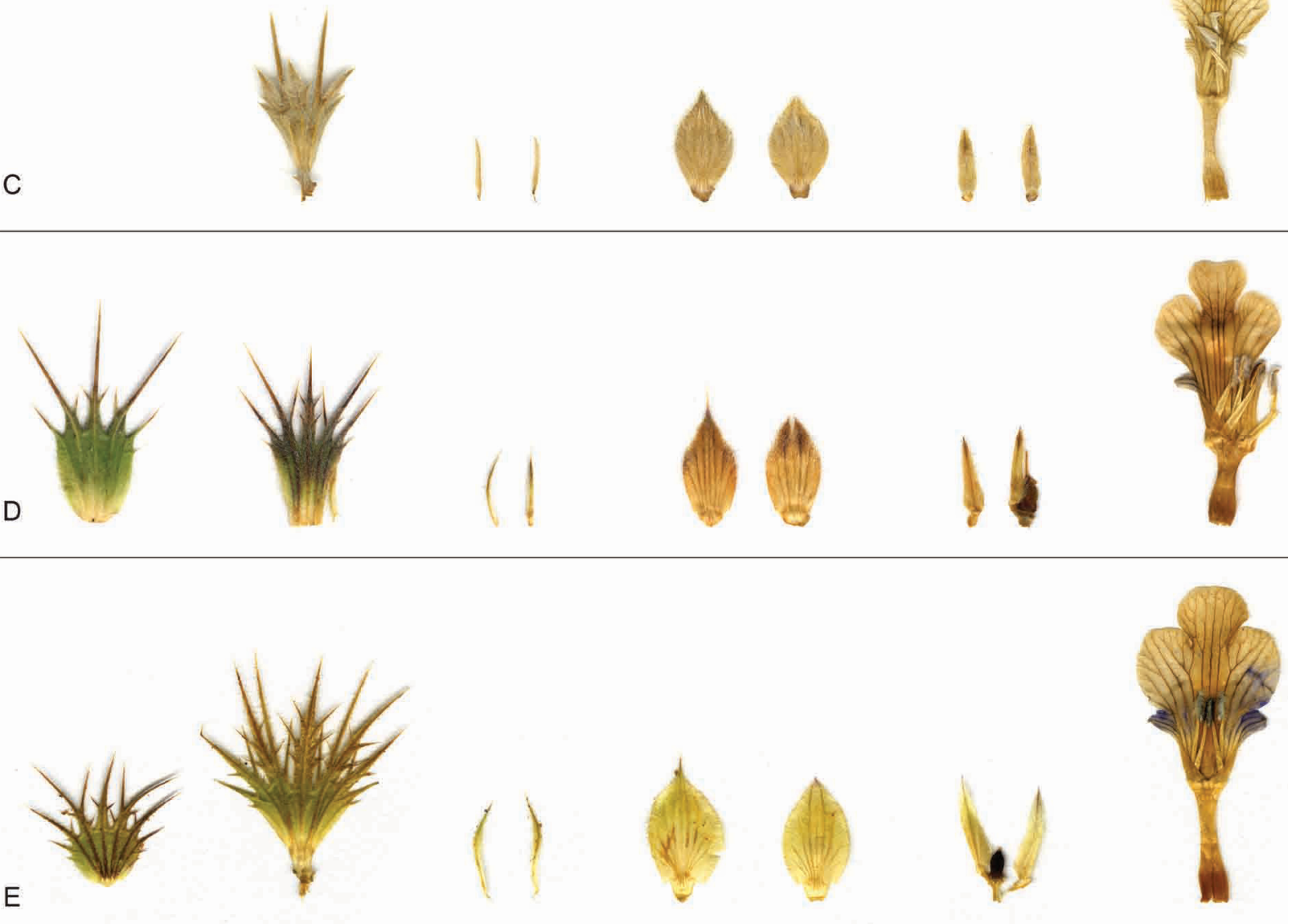

Figure 3 , continued on next page 

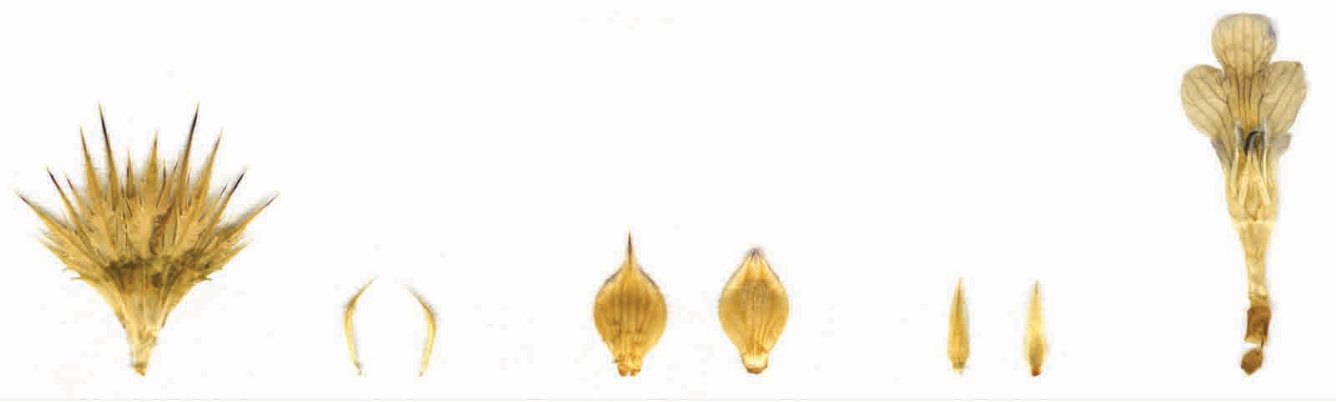

G
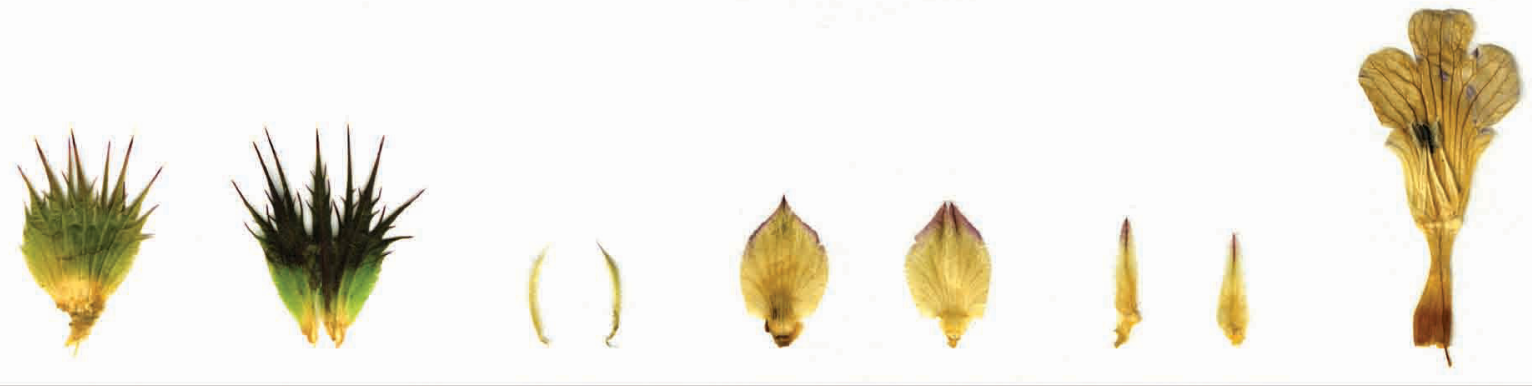

FIGURE 3. Comparison of floral parts in members of the Acanthopsis disperma-hoffmannseggianna species complex (from left to right): bract(s) (abaxial views), bracteoles, calyx (4 sepals) and flower. A. A. tuba. B. A. ludoviciana. C. A. adamanticola. D. A. villosa. E. A. hoffmannseggiana. F. A. disperma. G. A. dispermoides. Note: if two bracts per species are illustrated, the one on the left is from lower down in the same inflorescence. Scale bar $=10 \mathrm{~mm}$. Vouchers: A = Von Staden CNR $9139(\mathrm{PRE}), \mathrm{B}=$ Koekemoer $4370(\mathrm{PRE}), \mathrm{C}=$ Germishuizen 10074 (PRE), D = Koekemoer 4398 (PRE), E = Steyn 1907 (PRE), F = Koekemoer 4187 (PRE), G = Steyn 1912 (PRE).

\section{Materials and Methods}

Fieldwork was conducted over three seasons to assess the variation of live plants in nature, and to collect spirit material, herbarium specimens, DNA samples and photographic images. Relevant herbarium specimens held at BOL, $\mathrm{K}, \mathrm{KMG}, \mathrm{M}, \mathrm{NBG}, \mathrm{NMB}, \mathrm{P}, \mathrm{PRE}, \mathrm{PRU}, \mathrm{SAM}$ (in NBG) and WIND, together with high resolution images of herbarium specimens from JSTOR (2013) and from the herbaria of B-W, BM, GZU, K, S, TCD and Z, were studied (acronyms after Holmgren et al. 1990). For the demarcation of infrageneric taxa, a classical comparative morphological approach was followed. Provisional molecular analysis (gene regions $r p l 32-t r n L$, rbcLa, matK and rps16) did not show any potential to assist in resolving taxa at infrageneric level (unpublished data).

Digital images to illustrate some of the characters under magnification were obtained with a Zeiss DiscoveryV8 Stereo microscope. All measurements were taken from herbarium specimens; most measurements of floral parts were taken from additional pressed material collected by the author so as to minimize damage to existing herbarium specimens. Terminology used follows the definitions in Beentje (2010). Genus-specific terms applicable to the spinescent bracts are explained under "Results". Descriptors used to indicate abundance and frequency follow Schmid (1982).

In the sections "Additional specimens examined", locality citations were reproduced as given on the specimen labels, except for most WIND specimens where the original German labels were translated into English. In a few cases the locality names were corrected and are shown in square brackets. The specimens are arranged according to the Degree Reference System (Edwards \& Leistner 1971); the quarter degree grid reference is supplied between brackets after each locality cited. However, all specimen localities were georeferenced as accurately as possible and these values were used for mapping and conservation assessments. Conservation assessments follow the standard procedure based on IUCN guidelines (Raimondo et al. 2009). 


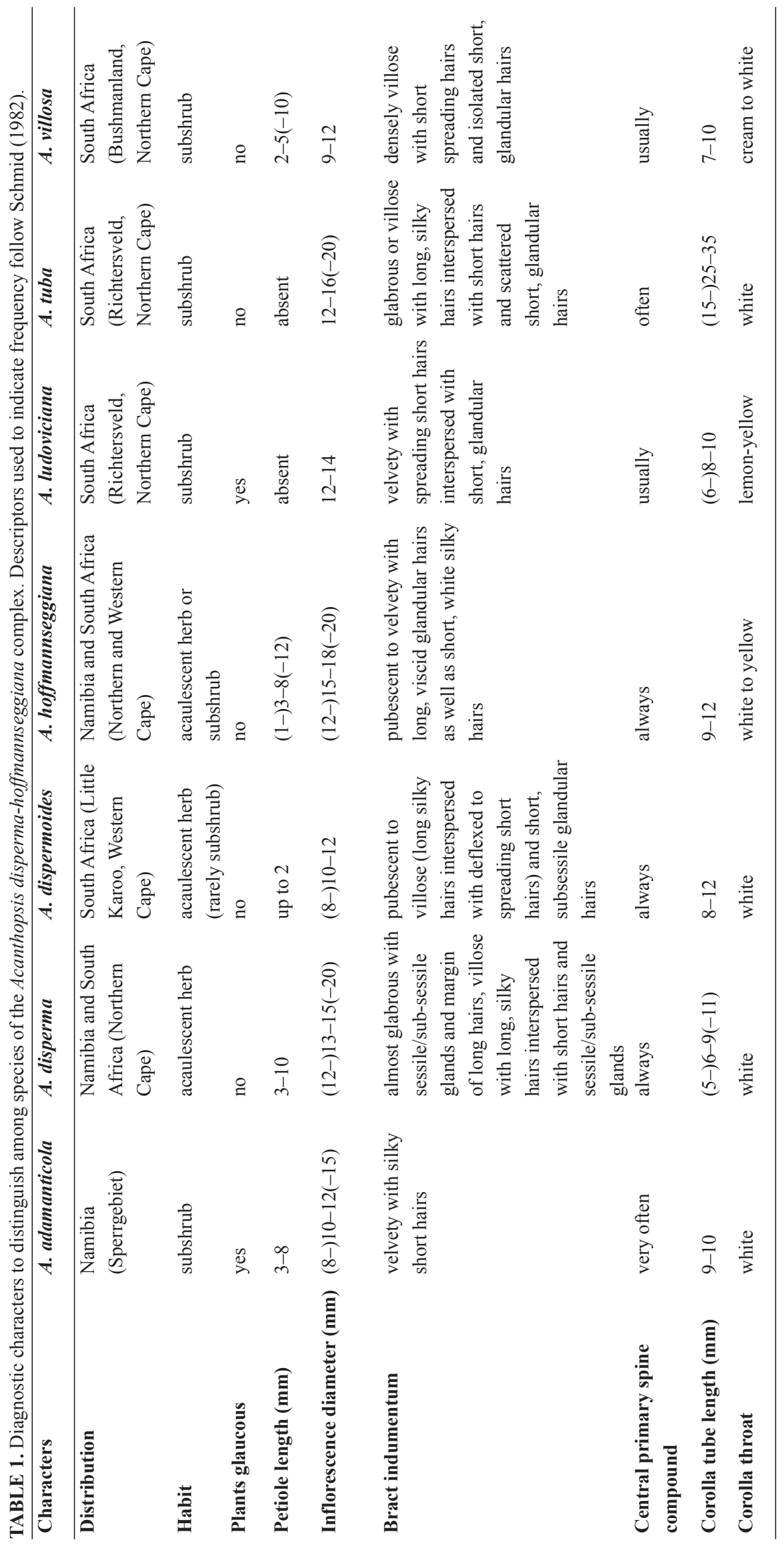




\section{Results}

Acanthopsis species can generally not be reliably identified using a single character and nearly always a combination of several characters are required, e.g. features derived from distribution range, life cycle, habit, leaves, inflorescences, flowers and bracts (see Table 1). Moreover, most of the diagnostic characters are not reliably displayed by juvenile plants, whether sterile or fertile. Fertile mature plants (to distinguish between annuals or biennials/perennials and subshrubs or shrubs) are usually essential for positive identification. Collectors of Acanthopsis herbarium material should record as much descriptive information as possible when out in the field (notably habit, life cycle, plant colour, flower colour). It must be emphasized that especially in the case of herbarium material, but also in the field, it would sometimes not be possible to identify Acanthopsis material to species with confidence.

In Acanthopsis the morphology of the bracts is taxonomically particularly useful. Bract shape and indumentum not only vary considerably among species and specimens, but also within a specific inflorescence. Therefore, the middle to upper bracts within an inflorescence were used in the keys and descriptions (except were stated otherwise). The bracts are stiff, apically 3-7-lobed, with each lobe ending in a spine. Terminology used to describe the spines associated with the bracts is illustrated in Fig. 2 and is here explained in more detail. The number of spinescent lobes corresponds with the number of clearly visible primary veins running more or less parallel in the blade of the bract. We refer to these lobes as the "primary spines", readily identified in that each contains an extension (at least basally) of one of the prominent veins. Additional spines may be found on the margins of the primary spines, or arise from their bases or the sinuses amongst them. We refer to these additional spines as "secondary spines", more specifically and depending on position, "marginal spines" or "basal spines". Secondary spines may be shorter or longer (especially the basal ones) than the primary spines but, unlike the latter, they are not an extension of one of the bract's prominent main veins. Primary spines without secondary spines are "simple", whereas those with secondary spines are "compound".

\section{Taxonomy}

\section{Interim key to major artificial species groupings in Acanthopsis}

1. Plants shrubby with well-developed branches and clearly visible internodes (usually up to 20(-25) mm long); leaves scattered (well-spaced) along woody stem ................................................................................................. Shrubby group (ca. 4 species) Plants acaulescent (rosulate), or compact subshrubs with gnarled stems and reduced (usually not visible) internodes (usually

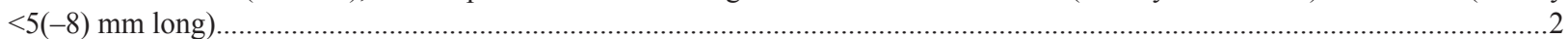

2. Inflorescence an open spike (often appearing pedunculate) with flowers clearly decussate; bracts not or slightly overlapping ........ Open-spike group (ca. 3 species) Inflorescence a dense (usually appearing sessile) spike with flowers not clearly decussate; bracts slightly to largely overlapping ..

3. Middle and upper bracts with central primary spine simple (without secondary spines), or with only 1 pair of secondary spines; corolla tube never longer than $15 \mathrm{~mm}$.

Dense spike with simple spines group (ca. 4 species; also specimens of $A$. adamanticola with young inflorescences-see present treatment)

- $\quad$ Middle and upper bracts with central primary spine compound (with 2 or more pairs of secondary spines); if central primary spine simple, then corolla tube markedly elongated $(>15 \mathrm{~mm}$ long)

.A. disperma-hoffmannseggiana complex (see key to species below)

\section{Key to the species of the Acanthopsis disperma-hoffmannseggiana complex (comparison of species also supplied in Table 1)}

1. Flowers with corolla tube markedly elongated, $>15 \mathrm{~mm}$ (usually $>25 \mathrm{~mm}$ ) long (Richtersveld, Northern Cape, South Africa) ......

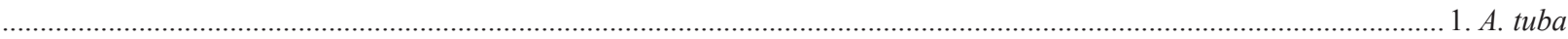
Flowers with corolla tube relatively short, up to $15 \mathrm{~mm}$ long (Namibia; Northern and Western Cape, South Africa) ...................2 Plants glaucous (blue-green or blue-grey); leaf indumentum usually of densely packed, appressed, short hairs ........................... 3 Plants various shades of dark green, but never glaucous; leaf indumentum of sparsely arranged, appressed, strigose or spreading hairs ......

3. Leaf margin undulate, coarsely dentate-spinose with long, yellowish orange spines; leaves sessile with base decurrent; corolla throat yellow (Richtersveld, Northern Cape, South Africa) ……...................................................................... 2. A. ludoviciana Leaf margin flat to undulate, spinose with short, fine yellow spines; leaves with petiole 3-8 mm long; corolla throat white (Sperrrgebiet,

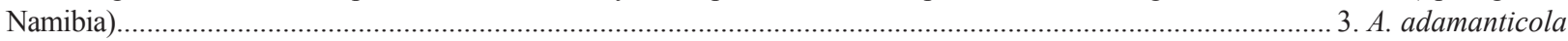

4. Bract lobes with long, viscid glandular hairs $0.2-0.3(-0.4) \mathrm{mm}$ long, or if from Kenhardt-Pofadder area, then usually also with 
silky villose indumentum (glandular hairs present but difficult to see); if glandular hairs on bracts shorter than $0.2 \mathrm{~mm}$, then leaf

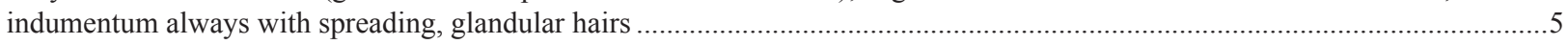
Bract lobes without viscid glandular hairs, or if glandular hairs present, then sessile to subsessile; leaf indumentum variable, but not with spreading glandular hairs and not densely villose......

5. Plants biennial/perennial subshrubs; inflorescences 9-12 $\mathrm{mm}$ in diameter; leaves (and inflorescences) densely villose (Bushmanland, Northern Cape, South Africa) ................................................................................................................. A. . villosa Plants annual to short-lived perennial acaulescent herbs or subshrubs; inflorescences $(12-) 15-18(-20) \mathrm{mm}$ in diameter; leaves never densely villose (Namibia to Western Cape, South Africa) .................................................................. 5. A. hoffmannseggiana Plants annual acaulescent herbs; inflorescences (12-)13-15(-20) $\mathrm{mm}$ in diameter; bract lobes almost glabrous to villose (Namibia to Richtersveld, Northern Cape, South Africa) .......................................................................................... 6. A. disperma Plants biennial/perennial acaulescent herbs (seldom subshrubs); inflorescences (8-)10-12 $\mathrm{mm}$ in diameter; bract lobes villose, never glabrescent (Little Karoo, Western Cape, South Africa) ........................................................................ 7. A. dispermoides

All the species of Acanthopsis recognized here (Table 1) have the following character states in common: inflorescences sessile (no distinct peduncle), dense, erect spikes with overlapping bracts; each flower supported by a single bract and two bracteoles; bracteoles linear-lanceolate with a bony midrib ending in a spinous tip; calyx 4-partite with the basal parts and veins thickened and bony; dorsal sepal longer and wider than the ventral one with both much wider than the lateral sepals, the dorsal sepal enveloping the other three; ventral sepal 2-fid, ending in spinous tips; lateral sepals lanceolate, broader at the base; corolla tubular at the base, 1-lipped, 5-lobed with the outer lobes reduced (see Fig. 3), pubescent to villose abaxially (outside), with barb-shaped hairs adaxially (inside); stamens 4 per flower with anthers densely bearded; filaments hard and bony, outer stamen filaments without an appendage at the tip; style unbranched, filiform with the stigma a single flattened lobe.

\section{Acanthopsis tuba H.M.Steyn, sp. nov. (Figs. 1, 3A, 4)}

Acanthopsis tuba differs from all other species of Acanthopsis in having a markedly elongated ( $>15 \mathrm{~mm}$ long) corolla tube.

Type:-[SOUTH AFRICA. Northern Cape:] Little Namaqualand, Steinkopf District. Flats at Anenous, 530 m, (2917BA), 20 August 1925, Marloth 12222 (holotype PRE0129530-0!; isotypes PRE0863286-0!, NBG0274649-0!).

A. carduifolia sensu Williamson (2000: 188 fig.), misapplied name, non (L.f.) Schinz.

Perennial, compact subshrub, 80-100 mm tall with reduced branching. Leaves oblanceolate, 40-60(-70) $\times 8-10(-12)$ $\mathrm{mm}$; margin undulate, coarsely dentate spinose, spines strong, $(2-) 4-8(-14) \mathrm{mm}$ long, yellow; almost glabrous or with minute appressed to spreading hairs; base attenuate, decurrent. Inflorescences $2-5$ per plant, $45-70 \mathrm{~mm}$ long, $12-16(-20) \mathrm{mm}$ in diameter. Bracts hemispherical, obovate or wedge-shaped, 22-32(-35) $\mathrm{mm}$ long, base 15-16 mm long, lower bracts truncate, ending in 7 primary spines (central primary spine simple, rest with short basal secondary spines); middle and upper bracts ending in 7 primary spines; central primary spine often compound (with 2 pairs of marginal secondary spines); other primary spines usually with 1 or 2 basal and (0)1 or 2 marginal secondary spines; spines spreading in fruit; bract base glabrous to hirsute with deflexed to spreading short hairs and scattered long hairs; ring of long, silky hairs adaxially at base of spines; spines almost glabrous or villose (long, silky hairs interspersed with short hairs and sparsely scattered to occasional short, glandular hairs). Bracteoles sickle-shaped, 8-9 mm long, silky hairy especially at tip, rarely also with glandular hairs. Calyx with dorsal sepal obovate, apiculate, 11-14 mm long, silky hairy especially abaxially, rarely also with glandular hairs, 7-9-veined from base; ventral sepal ovate, 10-13 $\mathrm{mm}$ long, silky hairy especially abaxially, occasionally also with glandular hairs, 5-7-veined from base; lateral sepals $9 \mathrm{~mm}$ long, densely silky hairy especially at base, occasionally also with glandular hairs. Flowers blue to deep bluepurple with white throat and dark purple ring around entrance to throat; corolla $45-50 \times 10-12 \mathrm{~mm}$, tube (15-)25-35 $\mathrm{mm}$ long, villose; corolla limb recurved, central lobe longer than wide or equal, slightly constricted at base, truncate to emarginate. Stamens with purple-black anthers, $2 \mathrm{~mm}$ long; filaments 4-5 $\mathrm{mm}$ long, glandular, hairy towards base. Style with patch or ring of glandular hairs at base. Capsules and seeds not seen.

Etymology:- - The specific epithet refers to the markedly elongated corolla tube; from the Latin tuba, a Roman bronze war trumpet with a long straight tube.

Distribution, ecology and phenology:- Centred in the core part of the Gariep Centre of Endemism (Van Wyk \& Smith 2001) and only known from three localities between Anenous and Helskloof in the Richtersveld, Northern Cape, South Africa (Fig. 1). This distribution falls within the Succulent Karoo Biome (Rutherford \& Westfall 1994, Low \& Rebelo 1996, Mucina \& Rutherford 2006) and within the Southern Richtersveld Scorpionstailveld (SKr 13) and 
Central Richtersveld Mountain Shrubland (SKr 1) vegetation types (Mucina \& Rutherford 2006). The mean annual precipitation in its range is $80-200 \mathrm{~mm}$, received mainly in winter. This species seems to be habitat specific (L. von Staden, pers. comm. 2014) and specimens were collected at elevations of 350-600 m on plains or hill slopes in welldrained rocky soils. Flowering time: August and September.
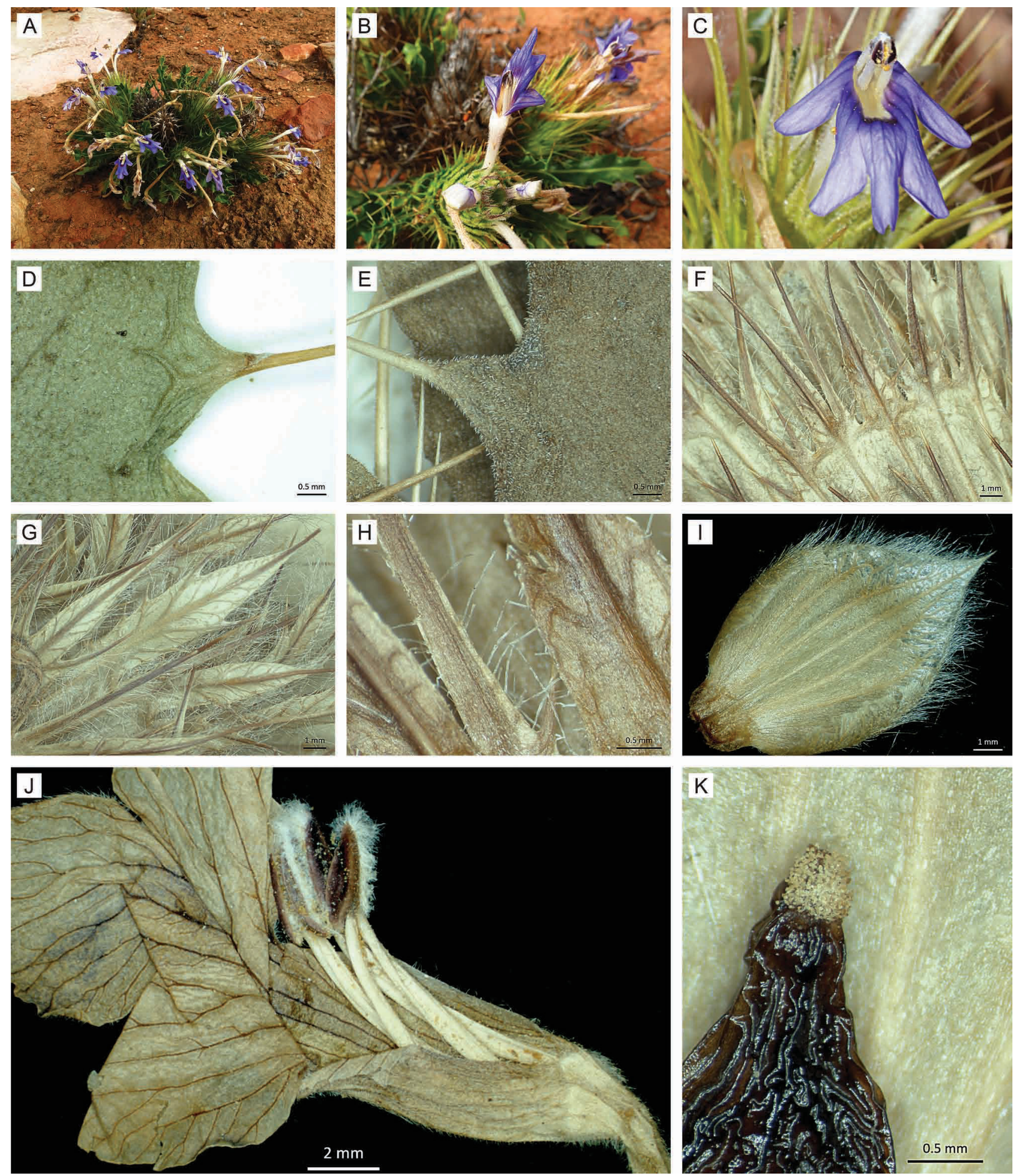

FIGURE 4. Acanthopsis tuba: morphology. A \& B. Habit. C. Flower. D \& E. Leaf indumentum. F-H. Bract. I. Calyx. J. Flower (corolla lobes blue-purple; throat white). K. Glandular hairs at base of style. Vouchers: D, I, K = Oliver, Tölken \& Venter 181 (PRE), E = Oliver, Tölken \& Venter 800 (PRE), F-H, J = Marloth 12222 (PRE). Photographs: L. von Staden (A \& B), P. van Wyk (C).

Notes:- The specimen collected from the top of Helskloof (Oliver, Tölken \& Venter 181) has villose bract lobes and the leaves are covered with minute appressed to spreading hairs in contrast to the almost glabrous specimens from further south. 
More fieldwork is needed to determine the full distribution range and abundance of this species.

Conservation status:- Acanthopsis tuba has an Extent of Occurrence of $1619 \mathrm{~km}^{2}$, and is known from only three locations, all in areas where severe overgrazing and trampling by domestic livestock are causing continuing loss and degradation of the habitat. Searches have failed to locate this species at two of the three known historical locations, and continuing population decline is inferred. It is therefore categorised as Endangered according to Red List criterion B1ab(iii,v) (IUCN 2001) (L. von Staden, pers. comm. 2014).

Additional specimens examined:-SOUTH AFRICA. Northern Cape: Richtersveld. Vandersterrberg; NE of Khubus. N end of the top of Helskloof and SE of Paradysberg western slopes to summit, (2817AC), 28 August 1977, Oliver, Tölken \& Venter 181 (PRE!); Richtersveld. Karuchabpoort, 9 km south of Lekkersing. Main hills north of poort, 350 m, (2917AA), 8 September 1977, Oliver, Tölken \& Venter 800 (PRE!); Richtersveld, Karachab Poort, between Eksteenfontein and Lekkersing, plateau of steep rocky slopes on northern side of road, near Eksteenfontein end of poort, (2917AA), 28 August 2014, Von Staden CNR 9139 (PRE!).

\section{Acanthopsis ludoviciana H.M.Steyn, sp. nov. (Figs. 1, 3B, 5)}

Acanthopsis ludoviciana differs from A. disperma in being a perennial subshrub with gnarled stems and short internodes ( $v s$. an acaulescent herb), sessile decurrent leaves (vs. petiolated leaves), and a glaucous appearance due to densely packed, short, appressed hairs on the leaves ( $v s$. green leaves with appressed, strigose or spreading hairs). In addition, A. ludoviciana has a lemon-yellow corolla throat ( $v$ s. the white throat of both $A$. disperma and $A$. adamanticola). It further differs from $A$. adamanticola in having sessile, decurrent leaves (vs. petiolated leaves), inflorescences $12-14 \mathrm{~mm}$ in diameter ( $v s$. (8-) $10_{-}$ $12(-15) \mathrm{mm}$ in diameter) and a distribution range in the Richtersveld, Northern Cape (vs. the Sperrgebiet in Namibia).

Type:-SOUTH AFRICA. Northern Cape: Richtersveld National Park, Helskloof Pass amongst Aloe pearsonii, 514 m, (2816BD), 3 September 2012, Koekemoer 4370 (holotype PRE0861488-0!; isotypes KMG!, NBG!).

\section{A. hoffmannseggiana sensu Williamson (2000: 189 fig.), misapplied name, non (Nees) C.B.Clarke.}

Perennial, rounded subshrub up to $300 \mathrm{~mm}$ high, with gnarled stems and short internodes $(<5(-8) \mathrm{mm}$ long). Leaves oblanceolate, 40-60(-80) × 10-15(-20) mm; margin undulate, coarsely dentate spinose, spines rigid, 3-5(-6) mm long, yellowish orange; glaucous with appressed, densely packed short hairs; base attenuate, decurrent, often with tufts of long, silky hairs. Inflorescences 35-60(-75) $\mathrm{mm}$ long, 12-14 mm in diameter. Bracts obovate to wedge-shaped, (17-)20-24 mm long, base 8-11 mm long; middle and upper bracts ending in 5 primary spines, central primary spine usually broadest and compound (with 2 or 3 pairs of marginal secondary spines, occasionally with only 1 pair of marginal spines), lateral spines usually with 1 or 2 basal and 2 or 3 marginal secondary spines; primary spines usually recurved and secondary spines spreading in fruit; bract base pubescent with deflexed to spreading short hairs (often also with scattered long hairs), long, silky hairs adaxially; spines velvety with spreading short hairs interspersed with short glandular hairs (rarely villose-see Notes). Bracteoles sickle-shaped, 7-8(-10) mm long, silky hairy especially towards tip. Calyx tips usually tinged brown, with long, white hairs clearly visible between bracts; dorsal sepal obovate, cuspidate, 11-14 mm long, densely silky hairy, 7-9-veined from base; ventral sepal ovate, 11-13 mm long, densely silky hairy, 5-7-veined from base; lateral sepals 7-8(-10) $\mathrm{mm}$ long, densely silky hairy. Flowers blue-purple with lemon-yellow throat; corolla 22-28(-32) $\times 11-13 \mathrm{~mm}$, tube $(6-) 8-10 \mathrm{~mm}$ long; central lobe wider than long or equal, constricted at base, truncate to emarginate. Stamens with beige-brown (sometimes purplish) anthers, $2 \mathrm{~mm}$ long; filaments 4-5 mm long, glandular. Style with ring of glandular hairs at base. Capsules ovate in face view, flattened, glabrous, shiny, 6-8 × 3-4 mm, 2-seeded. Seeds (4-)5 × $3 \mathrm{~mm}$, covered with long white hygroscopic hairs.

Eponymy:-Named after Louis Johannes Steyn [1999-], the first author's godson; ludoviciana is the Latinised version of "Louis".

Distribution, ecology and phenology:-Acanthopsis ludoviciana is centred in the core part of the Gariep Centre of Endemism (Van Wyk \& Smith 2001) and is only known from Helskloof and surroundings in the Richtersveld, Northern Cape, South Africa (Fig. 1). It is endemic to the Succulent Karoo Biome (Rutherford \& Westfall 1994, Low \& Rebelo 1996, Mucina \& Rutherford 2006) and falls within the Central Richtersveld Mountain Shrubland (SKr 1) vegetation type (Mucina \& Rutherford 2006). This area receives dense fog with associated condensation and the mean annual precipitation (mainly in winter) can be as high as $200 \mathrm{~mm}$, but for most of the areas it is probably less than 90 $\mathrm{mm}$. Acanthopsis ludoviciana grows on mountain slopes between elevations of $240-980 \mathrm{~m}$, and prefers loamy sand to sandy soils derived from weathered granite and quartzite. Flowering time: August and September. 

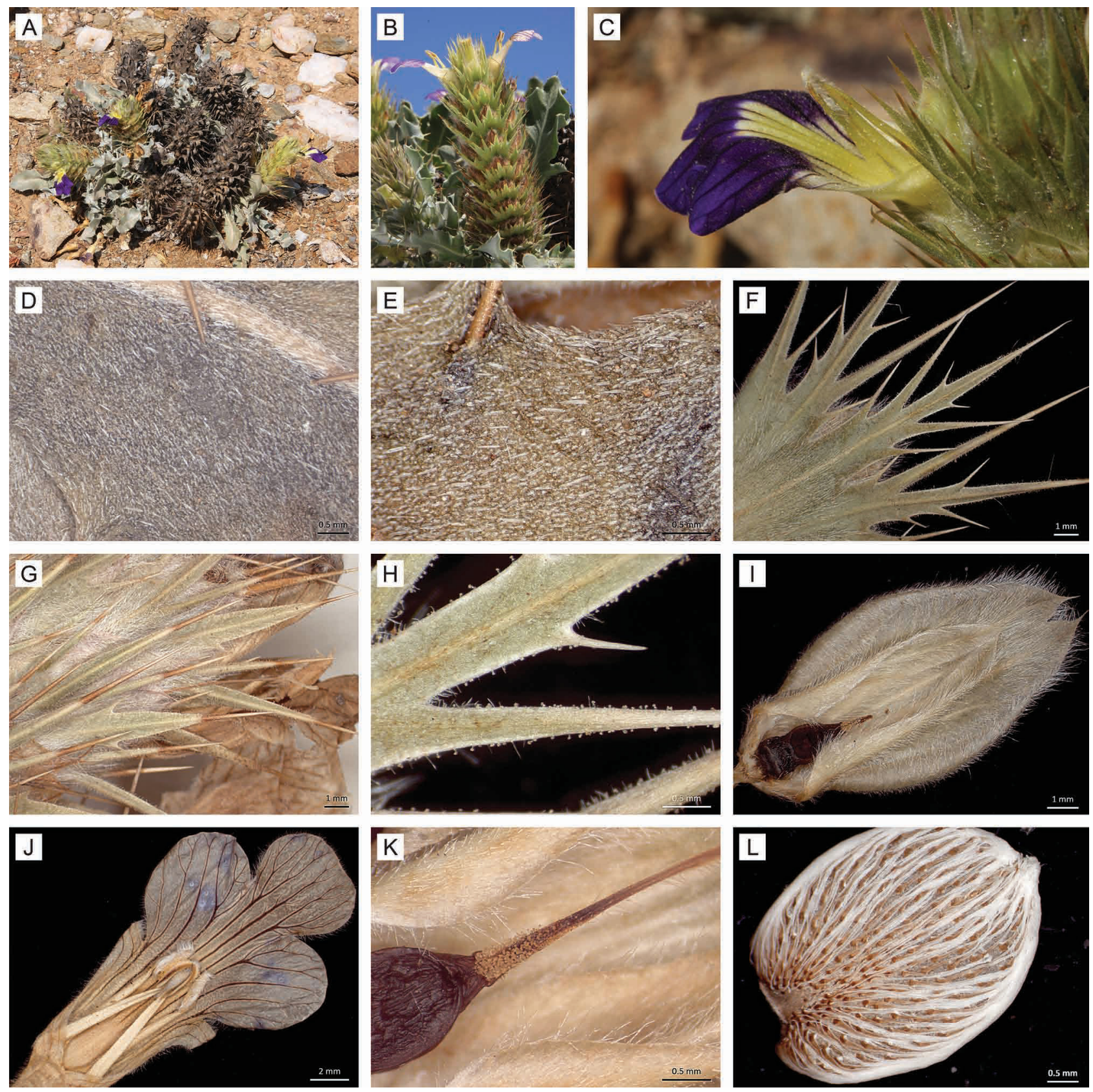

FIGURE 5. Acanthopsis ludoviciana: morphology. A-C. Habit. D \& E. Leaf indumentum. F-H. Bract. I. Calyx. J. Flower (corolla lobes blue-purple; throat lemon-yellow). K. Glandular hairs at base of style. L. Seed. Vouchers: D, E, G, K, L = Steyn 1814b (PRE), F, H = Koekemoer 4370 (PRE), I, J = Steyn 1818 (PRE). Photographs: M. Koekemoer (A-C).

Notes:- Specimens collected from Numees Copper mine and Kodaspiek (Jürgens 10117, Nicholas 2502, Oliver, Tölken \& Venter 396 and Venter 8180), have bract spines with densely hairy (villose) margins in contrast to the rest of the specimens with velvety spines.

Conservation status:-Acanthopsis ludoviciana is localised, only known from four populations with an extent of occurrence of $206 \mathrm{~km}^{2}$. Within this area the species is locally common and the population appears stable. The area is, however, subjected to severe overstocking (mainly goats and sheep) and, should grazing pressure continue to increase, the population is potentially at risk. The species therefore qualifies for Vulnerable under criterion D2 (IUCN 2001) (L. von Staden, pers. comm. 2014).

Additional specimens examined:- SOUTH AFRICA. Northern Cape: Richtersveld. Kodaspiek, $980 \mathrm{~m}$, (2816BB), 2 September 1977, Oliver, Tölken \& Venter 396 (PRE!); Richtersveld. Kodaspiek, (2816BB), 1 September 1980, Venter 8180 (PRE!); Richtersveld, Numees Experimental site, (2816BD), September 1981, Jürgens 10117 (NBG!); Richtersveld; Helskloof, (2816BD), September 1953, Munro 1271 (PRE!); Richtersveld; Numees copper 
mine; on rocky mountain side, 244 m, (2816BD), 27 August 1987, Nicholas 2502 (PRE!); Namaqualand District. Richtersveld National Park. W end of Helskloof Pass, 558 m, (2816BD), 13 September 2010, Steyn 1815 (PRE!); Namaqualand District. Richtersveld National Park. Helskloof, on turn-off to Paradyskloof, 606 m, (2816BD), 15 September 2010, Steyn 1818 (PRE!); Hottentotparadysberg; head of Helskloof, 800 m, (2816BD), 28 August 1977, Thompson \& Le Roux 119 (NBG!, PRE!); Richtersveld; on top of Hellsberge, (2816BD), 10 September 1961, Van Breda 1299 (PRE!); Top of Helskloof. Area mountainous, rocky with Mesembryanthemaceae dominant, (2816BD), 15 September 1977, Van Jaarsveld 2542 (NBG!); Richtersveld National Park, Numees Mountain west of upper Helskloof, (2816BD), 19 July 2014, Van Wyk 303 (PRE!); Between Gannakouriep Camp and Helskloof turn-off, 385 m, (2817AC), 13 September 2010, Steyn 1814 b (PRE!); Namaqualand District. Richtersveld National Park. Helskloof, on turn-off to Paradyskloof, 493 m, (2817AC), 15 September 2010, Steyn 1819 (PRE!); Richtersveld, road up SW slope of Vandersterrberg, from Glybank campsite to Koeskopfontein, (2817AC), 25 August 2014, Von Staden CNR 9138 (PRE!).

\section{Acanthopsis adamanticola H.M.Steyn, sp. nov. (Figs. 1, 3C, 6)}

Acanthopsis adamanticola differs from A. disperma in being a biennial/perennial (vs. an annual herb), with a glaucous appearance usually due to short, flat appressed hairs on the leaves ( $v s$. green leaves with appressed, strigose or spreading hairs), usually with prominent tufts of long, silky hairs at the base of the petiole ( $v s$. no tufts of hairs at the base of petiole), thinner inflorescences (8-)10-12(-15) $\mathrm{mm}$ in diameter ( $v s .(12-) 13-15(-20) \mathrm{mm}$ in diameter), with slender primary bract spines usually covered with a short, velvety indumentum ( $v s$. broader primary spines almost glabrous to villose). Acanthopsis adamanticola is distinguished from A. ludoviciana by the white corolla throat ( $v s$. a lemon-yellow throat) and the more northwesterly distribution in the Sperrgebiet, Namibia (vs. the Richtersveld, South Africa).

Type:-NAMIBIA. Karas: Klinghardt Mountains, in basin. Sperrgebiet, (2715BD), 23 September 1996, Mannheimer \& Mannheimer 278 (holotype WIND!; isotype PRE0838901-0!).

A. disperma sensu Mannheimer et al. (2008: 219 fig.), misapplied name, non Nees.

Biennial or perennial, compact subshrub up to $100 \mathrm{~mm}$ high, with reduced branching (internodes 3-5(-7) $\mathrm{mm}$ long). Leaves oblanceolate $(30-) 40-60(-70) \times(7-) 10-15 \mathrm{~mm}$; margin flat to undulate, spinose, spines fine, up to $2(3) \mathrm{mm}$ long, yellow; appears glaucous, usually due to appressed, densely packed short flat hairs; often with scattered longer hairs on main vein; base attenuate; petiole 3-8 mm long, usually with tufts of long, silky hairs at base. Inflorescences 25-45(-65) mm long, (8-)10-12(-15) mm in diameter. Bracts cup-, wedge- or fan-shaped, 15-17 mm long, base 5-7 $\mathrm{mm}$ long, middle and upper bracts ending in 5 primary spines; central primary spine often much shorter than basal secondary spine from lateral primary spines and very often compound (with 2(3) pairs of marginal secondary spines); lateral primary spines usually with 1 or 2 basal and 0 or 1-4 marginal secondary spines; primary spines usually recurved and secondary spines spreading in fruit; bract base pubescent with deflexed to spreading short hairs, ring of long, silky hairs adaxially at base of spines; spines usually velvety with silky short hairs, rarely almost glabrous. Bracteoles straight to slightly curved with the broadest part near the base, 5-6 mm long, silky hairy especially at tip. Calyx with dorsal sepal ovate, apiculate to cuspidate, $10-11 \mathrm{~mm}$ long, densely silky hairy, 7-9-veined from base; ventral sepal ovate, (8-)9-10 mm long, densely silky hairy, 5-7-veined from base; lateral sepals 7-8 $\mathrm{mm}$ long, densely silky hairy. Flowers blue-purple with white throat; corolla $25 \times 9-11 \mathrm{~mm}$, tube 9-10 $\mathrm{mm}$ long; central lobe wider than long or equal, slightly constricted at base, truncate to emarginate. Stamens with dark brown anthers, $2 \mathrm{~mm}$ long; filaments 4-6 mm long, glandular, hairy towards base. Style with patch of glandular hairs at base. Capsules ovate in face view, flattened, glabrous, shiny, 6-7 $\times 3-4 \mathrm{~mm}, 2$-seeded. Seeds $4 \times 3 \mathrm{~mm}$, covered with long white hygroscopic hairs.

Etymology:-The specific epithet, adamanticola (from the Latin adamas = diamond and cola $=$ dweller), is in reference to the fact that this species is near-endemic to the Sperrgebiet (restricted diamond mining area) in southwestern Namibia.

Distribution, ecology and phenology:-Acanthopsis adamanticola is restricted to the inselbergs and rocky outcrops of the coastal plains of the Sperrgebiet and the western foothills of the escarpment northeast of Rosh Pinah, Namibia (Fig. 1) at elevations between 500-750 m (up to $1200 \mathrm{~m}$ in the southeast). This area falls within the Gariep Centre of Endemism (Van Wyk \& Smith 2001). It is found in sandy crevices associated with rocky outcrops and inselbergs in the Succulent Karoo of Rutherford \& Westfall (1994) or Desert and Succulent Steppe of Giess (1971). The plants receive winter rainfall of less than $100 \mathrm{~mm}$ per annum, with an average of more than 50 days of fog per year (Mendelsohn et al. 2002). Flowering time: mainly August-October. 

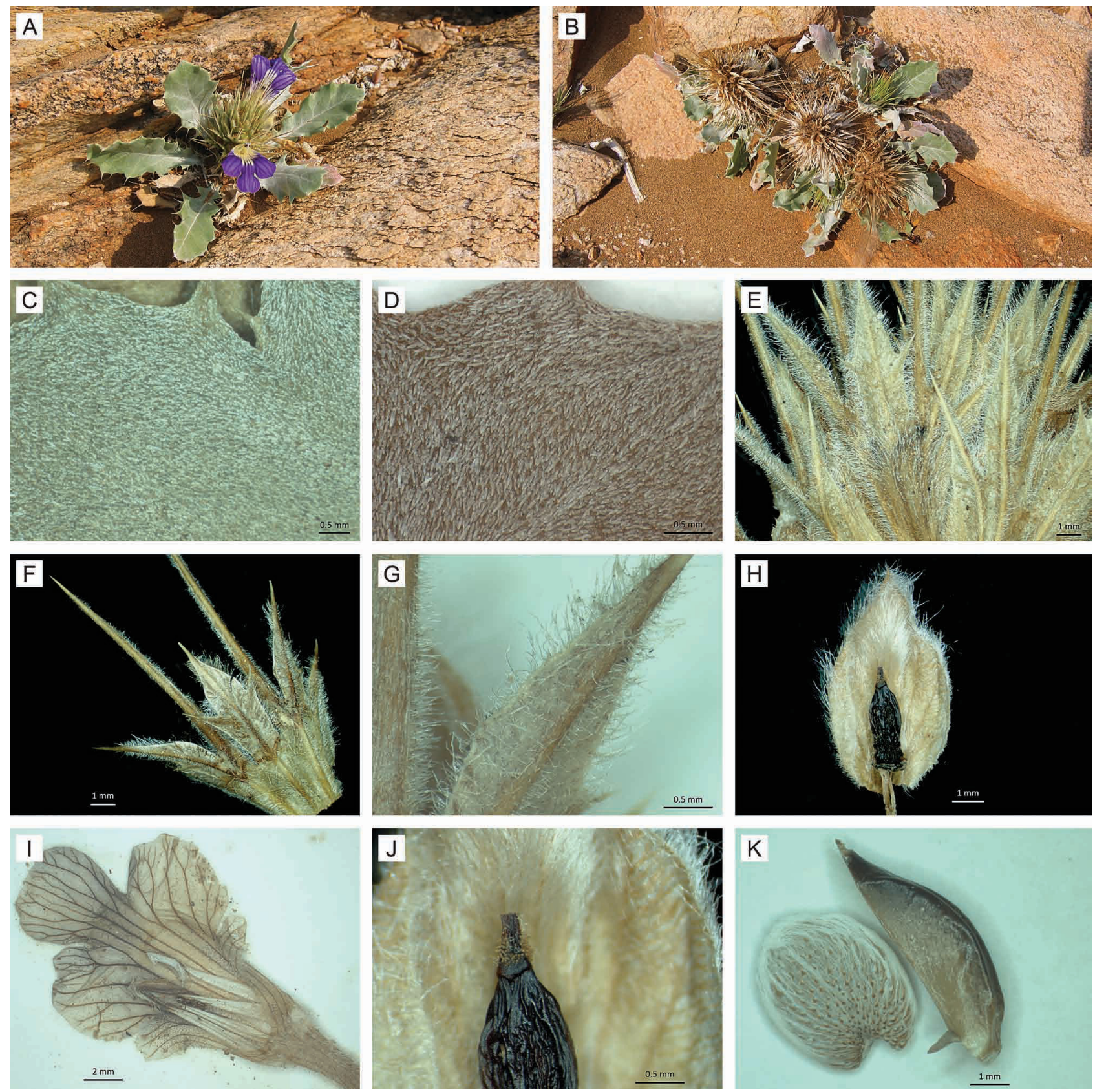

FIGURE 6. Acanthopsis adamanticola: morphology. A \& B. Habit. C \& D. Leaf indumentum. E-G. Bract. H. Calyx. I. Flower (corolla lobes blue-purple; throat white). J. Glandular hairs at base of style. K: Part of capsule and seed. Vouchers: C, E-J = Germishuizen 10074 (PRE), D = Bartsch, Loots \& Mannheimer SB1010 (WIND), K = Smook 11204 (PRE). Photographs: C. Mannheimer (A \& B).

On the label of Ward 13875 it is noted that the plants are "much eaten by game".

Notes:-Meyer (1961) noted that contrary to the species concept of Acanthopsis disperma, the collection of De Winter \& Giess 6183 is a perennial with " $4 \mathrm{~cm}$ long branches"; this specimen is here included in A. adamanticola.

According to Vollesen (2000) plants of Blepharis obmitrata C.B.Clarke (1901: 29) from the coastal desert (Namib) in Angola have a dense appressed silvery indumentum which is considered an adaptation to the special climate. Specimens from the higher lying areas around Rosh Pinah, Namibia, with prominent tufts of hairs at the base of the petiole and which appear glaucous but lack the typical short, flat appressed hairs on the leaves are preliminarily included in A. adamanticola: De Winter \& Giess 6330 (PRE!, WIND!), Giess 13800 (M!, PRE!, WIND!), Giess ex Wendt 14712 (WIND!), Giess 12941 (WIND!).

The Sperrgebiet and adjacent areas are still botanically under-collected and further fieldwork is necessary to clarify the relationships between $A$. adamanticola and $A$. disperma (hairy bract form), especially from the transitional zones between the ranges of these two species. 
Conservation status:-Acanthopsis adamanticola is a near-endemic of the Sperrgebiet National Park and restricted to inselbergs and rocky outcrops. Although the park has been fairly comprehensively collected during the past 15 years, this species is known from relatively few localities, with probably less than 10000 plants existing in the wild. As the park is being opened for tourism, including $4 \times 4$ routes and a lodge in the Aurus Mountains, a preliminary status of Rare (Raimondo et al. 2009) is assigned to this species (S. Loots, pers. comm. 2014).

Additional specimens examined:- NAMIBIA. Karas: $57 \mathrm{~km}$ from Rotkop on power-line track. SW slope of larger koppie, (2615DD), 23 October 1987, Kolberg \& Maggs 200 (PRE!); Diamond Area 1, foothills of Tsabiams Inselberg, 576 m, (2715BA), 4 September 2002, Bartsch, Loots \& Mannheimer SB1010 (WIND!); Klinghardtberge, südlicher Teil, Umgebung des [Klinghardt Mountains, southern part, vicinity of] 'Sargdeckel', (2715BC), 16 September 1977, Merxmüller \& Giess 32073 (M!, WIND!); Klinghardtberge, nördlicher Teil, Quartzithügel (NW), (2715BC), 18 September 1977, Merxmüller \& Giess 32146 (M!); Diamond Area 1, Klinghardt Mountains area: Kaiser's Camp, 500 m, (2715BC), 5 December 1996, Ward 13875 (PRE!); Diamond Area 1: Klinghardt Mountains, 700 m, (2715BD), 21 September 1996, Burke 96111 (WIND!); Klinghardt Mts., (2715BD), 20 September 1922, Dinter 3973 (BOL!, PRE!); Diamond Area No.1. Inselberg of Klinghardt Mountain Range, 728 m, (2715BD), 5 August 2001, Germishuizen 10074 (PRE!); Sperrgebiet; slopes of Tsaus Mountains. Hill slope, 278'20'S 16¹3'3”E (2716AA), 26 September 1996, Mannheimer 318 (PRE!, WIND!); Diamantgebied 1. Tsaus Spinnenberg, in Gestein [rocks], (2716AA), October 1977, Wendt 13/2 (WIND!); Sperrgebiet; eastern side of Klinghardt Mountains, 726 m, 27²6.02'S 1604.14'E (2716AC), 6 August 2001, Smook 11204 (PRE!, WIND!); Diamond Area No.1. Aurusberg Mountains. West side, 507 m, (2716CA), 8 August 2001, Germishuizen 10185 (PRE!); Sperrgebiet; northern end of Aurus Mountains on western side, $1988 \mathrm{ft}$, 2736.55'S 16²14.23'E (2716CA), 8 August 2001, Smook 11264 (PRE!, WIND!); Southern Namib: Diamond Area No. 1; Aurus Mountains (North), 630 m, 2731'S 16²11'E (2716CA), 22 April 1988, Ward \& Seely 10243 (PRE!, WIND!); Sperrgebiet; eastern side of Aurus Mountains at highest peak of range, 2738.95'S $16^{\circ} 18.98^{\prime} \mathrm{E}$ (2716CB), 10 August 2001, Smook 11314 (PRE!, WIND!); Diamond area no. 1; Aurusberge; hills, (2716CB), 23 October 1974, Watmough 875 (PRE!); Sperrgebiet: Bushmanberg, 661 m, (2716CD), 6 September 2003, Klaassen, Bartsch \& Loots EK1133 (WIND!); Diamond Area no 1. Gravelly flats at foot of stony mountain slopes. Obib Fountain, (2816BA), 4 September 1958, De Winter \& Giess 6183 (M!, PRE!, WIND!).

\section{Acanthopsis villosa H.M.Steyn, sp. nov. (Fig. 1, 3D, 7)}

Acanthopsis villosa is easily distinguished from A. disperma in being a small, perennial subshrub ( $v s$. an acaulescent herb) and from $A$. hoffmannseggiana in having inflorescences 9-12 $\mathrm{mm}$ in diameter (vs. (12-)15-18(-20) $\mathrm{mm}$ in diameter) and a densely villose indumentum on the leaves ( $v s$. leaves with strigose to spreading indumentum, never densely villose).

Type:-SOUTH AFRICA. Northern Cape: Namaqualand District. Boesmanplaat, along a turn-off to the west of the road between Gamoep and Platbakkies, 908 m, (3018AB), 16 August 2013, Koekemoer 4398 (holotype PRE0863486-0!; isotype NBG!).

Acanthus carduifolius Th. $\beta$ spica villosa E.Mey., ms. [name written on specimen] sensu Drège 2433 (P)

Perennial, compact subshrub, up to $70(-100) \mathrm{mm}$ tall with reduced branching and very short internodes $(<5 \mathrm{~mm}$ long). Leaves oblanceolate, $40-60(-70) \times(5-) 7-10 \mathrm{~mm}$; margin strongly undulate, dentate spinose to coarsely dentate spinose, spines fine to strong, $2-4 \mathrm{~mm}$ long, yellow; densely villose with long spreading hairs and short, spreading glandular hairs; base attenuate; subsessile or with petiole 2-5(-10) $\mathrm{mm}$ long. Inflorescences often attenuate to cuneate with a number of small, ovate to obovate sterile bracts at the base; $25-50(-70) \mathrm{mm}$ long and 9-12 $\mathrm{mm}$ in diameter; basal portion of bracts overlapping, rarely exposing parts of the inflorescence axis. Bracts hemispherical to wedgeshaped, 20-22 $\mathrm{mm}$ long, base 7-9 $\mathrm{mm}$ long; middle and upper bracts ending in 5 primary spines; central primary spine usually compound, with (1)2 or often 3 pairs of marginal secondary spines; 2 lateral primary spines usually with 1 long secondary spine (marginal or basal) directed towards central primary spine and $1(-3)$ much shorter additional marginal secondary spine(s); secondary spines usually shorter, occasionally equal to primary spines; spines spreading in flower and slightly recurved in fruit; bract base densely villose with long, spreading to atrorse hairs as well as short, deflexed hairs and short glandular hairs; spines glabrescent to villose with short spreading hairs as well as isolated short glandular hairs. Bracteoles linear, 8-9 mm long; densely silky hairy. Calyx with dorsal sepal ovate, cuspidate, 13-14 mm long, densely silky hairy; ventral sepal ovate, 10-11 mm long; densely silky hairy; lateral sepals $8 \mathrm{~mm}$ long, densely silky hairy. Flowers purple with cream to white throat, $24-26 \times 10-12 \mathrm{~mm}$, tube 7-10 $\mathrm{mm}$ long; central lobe usually broader than long, constricted at base, emarginate. Stamens with orangy-brown anthers, $2 \mathrm{~mm}$ long; filaments 
5-6 mm long, glandular with spreading hairs towards the base. Style with patch of glandular hairs at the base. Capsules ovate in face view, flattened, glabrous, shiny, $7 \times 3 \mathrm{~mm}$; 2-seeded. Seeds not seen.

Etymology:- The epithet refers to the densely villose (long, soft weak hairs) indumentum of the leaves and bracts.
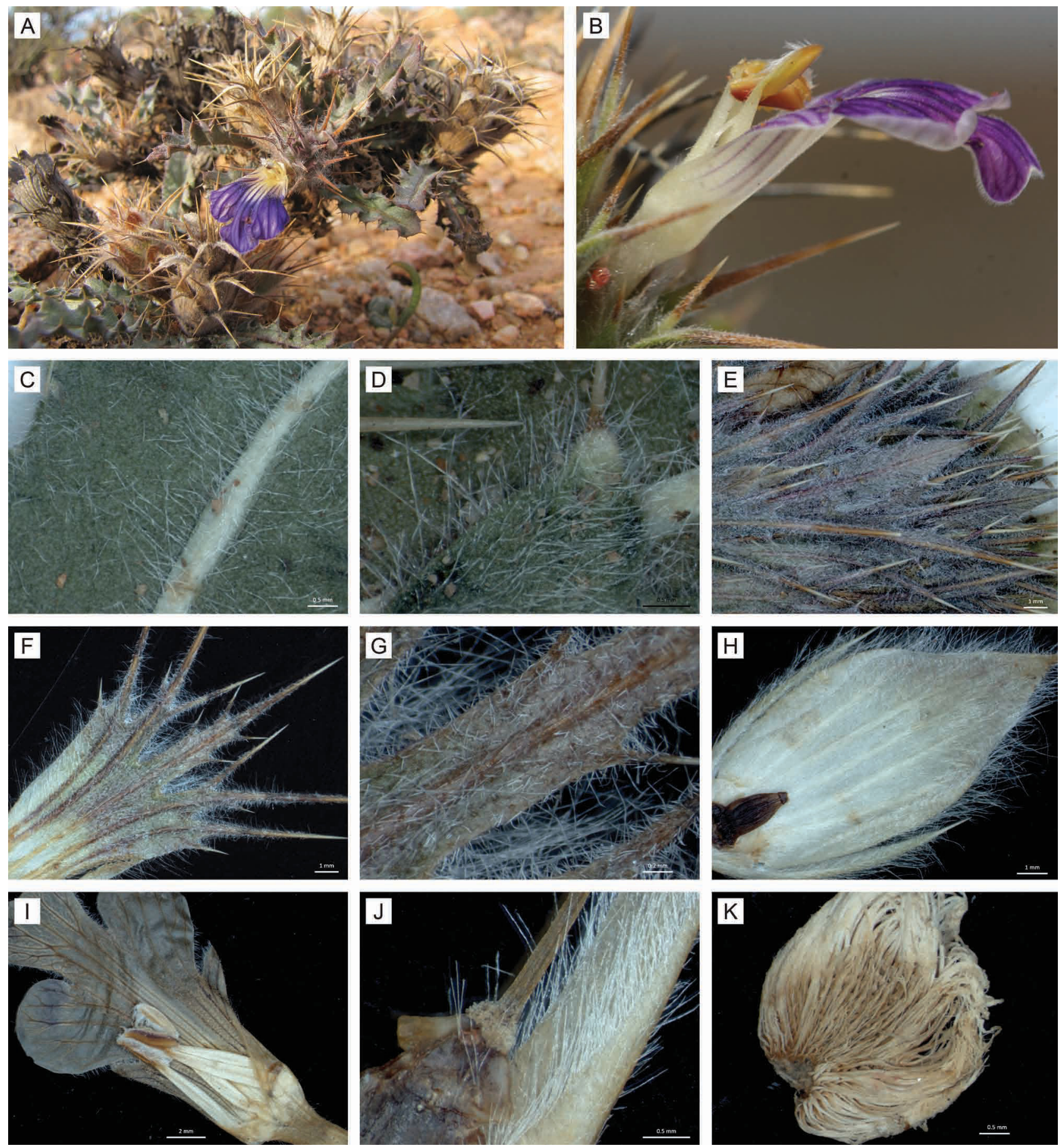

FIGURE 7. Acanthopsis villosa: morphology. A \& B. Habit. C \& D. Leaf indumentum. E-G. Bract. H. Calyx. I. Flower (corolla lobes blue-purple; throat white to cream). J. Glandular hairs at base of style. K: Seed. Vouchers: C-J = Koekemoer 4398 (PRE), K= Marloth ex Meyer 6395 (PRE). Photographs: N. Helme (A), M. Koekemoer (B).

Distribution, ecology and phenology:- Only known from a few localities on the plains or inselbergs in Bushmanland, east of the Kamiesberg range, Northern Cape, South Africa (Fig. 1). This distribution falls in the Namaqualand Hardeveld and Bushmanland Bioregions (Mucina \& Rutherford 2006) in the transitional zone between winter- and summer-rainfall regions (falling predominantly in autumn) in very dry areas with the mean annual precipitation ranging between less than 100-160 mm. It is found in the Succulent Karoo (Rutherford \& Westfall 1994, Low \& Rebelo 1996, Mucina \& Rutherford 2006) and Nama-Karoo Biomes (Rutherford \& Westfall 1994, Low \& Rebelo 1996). According to Mucina \& Rutherford (2006) and Desmet (2013) the localities within the Bushmanland Bioregion 
falls within outliers of Succulent Karoo vegetation (Succulent Karoo Biome) within the prevailing Bushmanland Arid Grassland (Nama-Karoo Biome). Specimens were collected at elevations of 900-1070 m, in well-drained sandy soils derived from granite and quartzite. Flowering time: mainly August to October.

Notes:-Although Drège's specimen (Drège 2433, in P) was included in the concept of Acanthodium carduifolium (L.f.) Nees in Candolle (1847:278), most herbarium specimens (which are now included in A. villosa), were misidentified as $A$. disperma (probably because of the dense inflorescences with bracts ending in a compound central primary spine, but without long, viscid glandular hairs), in contrast to A. hoffmannseggiana which has long, viscid glandular hairs on the bracts.

Conservation status:-Acanthopsis villosa has a restricted distribution (Extent of Occurrence $7458 \mathrm{~km}^{2}$ ), but is not threatened, and is therefore assessed as Least Concern (IUCN 2001) (L. von Staden, pers. comm. 2015).

Additional specimens examined:-SOUTH AFRICA. Northern Cape: Little Bushmanland, Aggeneys, Natken farm. North-facing slope of western portion of Naip se Berg $1 \mathrm{~km} \mathrm{NW}$ of Natken farm house, $1050 \mathrm{~m}, 29^{\circ} 21^{\prime} 34^{\prime \prime} \mathrm{S}$ 18¹7’04”E, (2918AD), 6 October 1999, Desmet 2028 (NBG!); $20 \mathrm{~km}$ east of Springbok on road to Pofadder, (2918CA), April 1970, Hugo 208 (NBG!); Namaqualand District. West of Ratelkraal, (2918CA), 7 September 1950, Maguire 330 (NBG!); Namaqualand Dist. 25 miles east of Springbok at the farm Areb, (2918CA), 6 August 1967, Rourke 804 (NBG!); Bushmanland, Vaalputs, NECSA Site, (3018AB), 2 August 2011, Van Rooyen 2790 (PRE!, PRU!); Little Namaqualand, Alewyn's Fontein, 950 m, (3018BD), 22 December 1908, Pearson 3346 (BOL!); Calvinia Div.; Braakfontein farm 33 mi. W [N?] of Loeriesfontein, (3019CB), 28 October 1963, Schlieben \& Van Breda 9849 (PRE!). Without precise locality: [Illegible] Kaus [Gebirge bei Goedemanskraal, Rustbank und Kookfontein, fide Drège (1843)], $3500 \mathrm{ft}$ (III B), Drège 2433 (P!), Marloth ex Meyer 6395 (PRE!).

5. Acanthopsis hoffmannseggiana (Nees) C.B.Clarke (1901: 35); Meyer (1961: 22); Balkwill (2012: 257) (Figs. 1, 3E, 8)

Type:- [SOUTH AFRICA. Northern Cape:] Cape of Good Hope [Without precise locality], Hoffmannsegg s.n. (lectotype B-W11728-010 scan! designated here; iso-lectotype GZU000251757, fragment scan!).

Acanthodium hoffmannseggianum Nees in Candolle (1847: 277).

Annual to short-lived perennial acaulescent herbs or subshrubs $100-150(-200) \mathrm{mm}$ tall with reduced branching in perennials (internodes $<5 \mathrm{~mm}$ long). Leaves tufted, oblanceolate, lanceolate to strap-shaped, (30-)50-90(-150) $\times$ $10-20(-25) \mathrm{mm}$; margin flat to undulate, irregularly dentate to coarsely dentate spinose; spines fine to strong, 2-4(-7) mm long; with strigose to spreading short hairs, usually interspersed with stalked glandular hairs; often with scattered longer hairs on main vein; base attenuate; petiole (1-)3-8(-12) mm long. Inflorescences (1-)3-5(-8) per plant; $25-$ 65(-85) $\mathrm{mm}$ long, (12-)15-18(-20) $\mathrm{mm}$ in diameter. Bracts hemispherical to fan-shaped, 18-23 $\mathrm{mm}$ long, base 6-8 $\mathrm{mm}$ long, middle and upper bracts ending in 5 primary spines; central primary spine always compound (with 2 or 3 pairs of marginal secondary spines), lateral primary spines with 2 basal and 3(-5) marginal secondary spines; primary spines usually recurved and secondary spines spreading in fruit; bract base hirsute to pubescent with deflexed to spreading short hairs interspersed with stalked glandular hairs and some scattered long, silky hairs; ring of long, silky hairs adaxially at base of spines; spines usually with long, viscid glandular hairs, 0.2-0.3(-0.4) $\mathrm{mm}$ long (see notes), often velvety due to additional short, white silky hairs (Western Cape), or villose due to additional long, white silky hairs (central Northern Cape, South Africa). Bracteoles lanceolate 6-9 mm long, silky hairy, often with glandular hairs at tip. Calyx with dorsal sepal ovate to obovate, cuspidate, 11-14(-15) mm long, silky hairy especially adaxially, often with glandular hairs abaxially, 7-9-veined from base; ventral sepal ovate, 9-11 mm long, silky hairy, often with glandular hairs abaxially; lateral sepals $9 \mathrm{~mm}$ long, densely silky hairy. Flowers with variable colours, white with purple veins, blue-purple with white throat, or yellowish; corolla (23-)25-30 × 9-12(-13) mm, tube 9-12 mm long; pubescent, often with some glandular hairs; central lobe longer than wide or equal, constricted at base, truncate to emarginate. Stamens with purple-black to brown anthers, $2 \mathrm{~mm}$ long; filaments $4-5 \mathrm{~mm}$ long, glandular, hairy towards base. Style with patch of glandular hairs at base. Capsules ovate in face view, flattened, glabrous, shiny, 6-7 $\times 2-3 \mathrm{~mm}$, 2-seeded. Seeds $4 \times 3 \mathrm{~mm}$, covered with long white hygroscopic hairs.

Eponymy:-The specific epithet commemorates the German botanist Johann Centurius von Hoffmannsegg [1766-1849] from whom Willdenow had received the type specimen.

Distribution, ecology and phenology:-Acanthopsis hoffmannseggiana is restricted to southeast Namibia and adjacent central South Africa (Northern Cape) with a disjunct outlier presence further south in the Western Cape) (Fig. 1). This range falls within the Nama-Karoo Biome (Rutherford \& Westfall 1994, Low \& Rebelo 1996, Mucina 
\& Rutherford 2006) where it receives predominantly late summer and autumn rains with an average of 100-300 mm per year. It prefers sandy plains, stony hillsides and ridges and is usually associated with weathered quartzite and granite, but also occurs on mudstone (in Prince Albert area) and limestone (Asbestos Mountains), usually at elevations between 650 and $1000 \mathrm{~m}$. The Afrikaans vernacular names klappers and jakobregop was recorded by Theron 821 and Wasserfall 1092 respectively. Shearing 58 noted that the thorns are very poisonous, and Wasserfall 1092 that the leaves are eaten by stock. Flowering time: mainly March-October, perennial form from Pofadder area flowers between August and March.
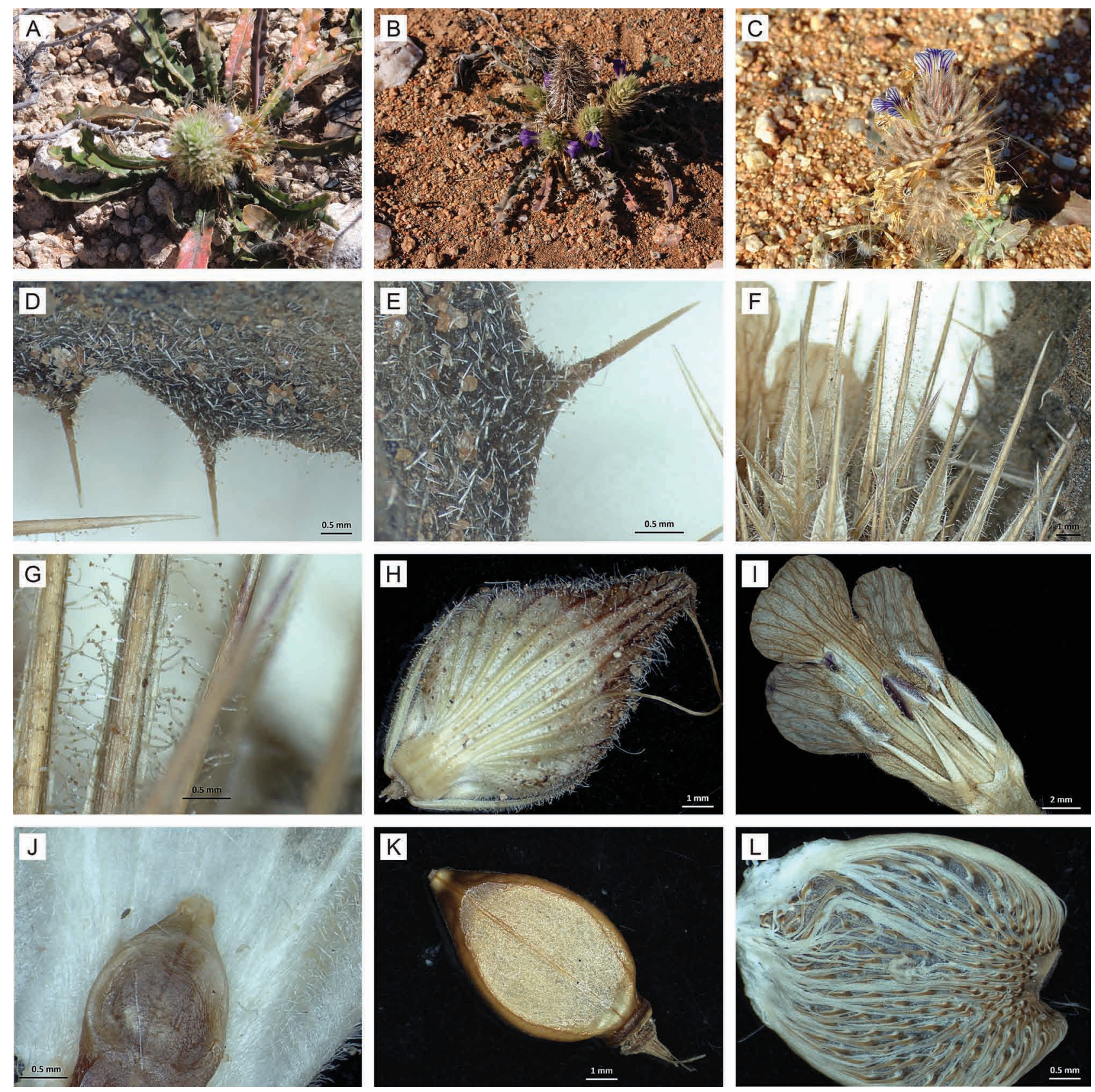

FIGURE 8. Acanthopsis hoffmannseggiana: morphology. A-C. Habit. D \& E. Leaf indumentum. F \& G. Bract. H. Calyx. I. Flower (corolla lobes variable colours; throat white or cream). J. Base of style. K. Capsule. L. Seed. Vouchers: D-G = De Winter 3558 (PRE), H = Steyn 1915 (PRE), I, J = Steyn 1895 (PRE), K, L = Smith PRE40539 (PRE). Photograph: M. Koekemoer (B).

Notes:-Ever since the establishment of Acanthodium hoffmannseggiana there has been confusion between the use of the names Acanthodium hoffmannseggiana and Acanthodium carduifolium. Nees in Candolle (1847) listed Acanthus carduifolius "(herb. Willdenow 11728)" (the specimen here selected as lectotype) in the protologue. On the type specimen (B-W11728-010) there are annotations alluding to both names: Ac [anthus] carduifolius (Schlechtendal's handwriting and probably why Nees mentioned this name), Acanthopsis carduifolia (L.) Schinz (Schinz's handwriting) and Acanthodium hoffmannseggianum (Nees' handwriting). Nees in Candolle (1847) also noted that Thunberg confused 
Acanthodium hoffmannseggiana with Acanthus carduifolia Linneaus (1782: 294). On both fragments in GZU, both names are in Nees' handwriting. However, Nees in Candolle (1847) stated that these two species certainly differ from each other and kept them separate as distinct species. In 1864 Anderson listed Acanthodium hoffmannseggianum as a synonym of Blepharis carduifolia Anderson (1864: 35), probably as a result of the confusing annotations on the specimens. This was upheld by Schinz (1890) who listed both names as synonyms of Acanthopsis carduifolia (L.f.) Schinz (1890: 200). Clarke (1901) resurrected A. hoffmannseggiana as a valid name and it has been acknowledged as a separate species since.

Acanthopsis hoffmannseggiana has the widest distribution of all Acanthopsis species and contains a number of different forms. The biggest variation occurs in the leaf and bract indumentum, flower colour, life cycle and distribution range. A villose bract form occurs mainly in the Kenhardt-Pofadder area, these plants are annuals (terophytes) usually with strap-shaped leaves (strigose indumentum), white, silky villose bracts (glandular hairs are often difficult to see) and white flowers with purple veins or lilac flowers with darker purple veins. A form with yellowish flowers occurs around Prieska and the Asbestos Mountains and a perennial herb/subshrub form with blue-purple flowers (white throat) occurs in the Prince Albert area in the Great Karoo and the Pofadder area in Bushmanland. The following specimens from the Pofadder area are included in A. hoffmannseggiana due to the leaf indumentum of spreading glandular hairs, life cycle (perennials), general appearance and distribution. These specimens, however, lack long, viscid glandular hairs on the bracts that characterise A. hoffmannseggiana, (Barker 8349, Sachse 893, Steyn 1908, Van Jaarsveld \& Kritzinger 8070). In the southern Great Karoo (just north of the Swartberg Mountains), specimens to the west of this outlier distribution range are somewhat intermediate between $A$. hoffmannseggiana and A. dispermoides (found to the south of the Swartberg Mountains) with the bract indumentum consisting of short glandular hairs ( $<0.2 \mathrm{~mm}$ long), with longer silky hairs on the margins (shorter and less dense than $A$. dispermoides), but the spreading, glandular leaf indumentum of A. hoffmannseggiana (Prince Albert form) (Acocks 17139, Bond, 841, Cattell \& Cattell 215, Snijman 2334, Steyn 1900, Thode STEU2700, Venter 1434). The taxonomic significance of these variation patterns is not clear at the moment.

As all the various forms seem to grade into each other, they are here all included in a rather broad concept of $A$. hoffmannseggiana. However, further fieldwork and taxonomic evidence (notably comparative studies on trichomes and pollen) might well result in the recognition of infraspecific taxa in future.

Conservation status:-Acanthopsis hoffmanseggiana as currently circumscribed is a widespread and very variable species and is classified as Least Concern (IUCN 2001) (L. von Staden, pers. comm. 2015).

Additional specimens examined:-NAMIBIA. Karas: Klein Karas, (2718CA), October 1913, Dinter 3218 (PRE!, SAM!); Farm Fortuin, (2719CD), 22 February 1997, Ströhbach, Kubirske \& Sheuyange 3010 (WIND!); Warmbad Dist.; 20 mi. on Goodhouse rd., hillside, (2818CB), 24 July 1937, Galpin 14206 (PRE!); Goodhouse Poort, (2818CD), 22 June 1989, Van Wyk 8593 (NMB!, PRE!, PRU!); Farm Lugeck: WAR 114. Im Rivierbett [In riverbed], (2818DB), 22 May 1972, Giess \& Müller 12117 (M!, PRE!, WIND!); Keetmanshoop Dist.; 30 mi. from Ariamsvlei on road to Ham River Station, (2819AB), 16 May 1955, De Winter 3558 (M!, NBG!, PRE!, WIND!); Tussen Ariamsvlei en Karasburg, (2819AB), 14 August 1961, Schweickerdt 2588 (PRU!); Warmbad: sandige Flächen und schwarze Hügel westlich Ariamsvley, (2819BA), 14 December 1957, Merxmüller \& Giess 746 (M!); Graswater: WAR 150. Granit-Quarzit Geröllfläche [Granite quartzite scree plain], (2819CB), 17 May 1963, Giess, Volk \& Bleissner 7044 (WIND!). SOUTH AFRICA. Northern Cape: Pofadder, $20 \mathrm{~km} \mathrm{~S}$ of Onseepkans, (2819CD), 16 July 1988, Dean 558 (J!); Gordonia District. Augrabies Waterfall National Park. New part of park, close to picnic spot (Af en Toe), $699 \mathrm{~m}$, (2819DB), 22 August 2005, Steyn 758 (PRE!); Kenhardt Div.; 14.2 mi. W of Bladgrond on Pofadder road, $3000 \mathrm{ft}$, (2819DC), 22 February 1954, Comins 656 (PRE!); Kenhardt District; on tarred road between N14 and Onseepkans., 866 m, (2819DC), 5 August 2013, Steyn 1910 (PRE!); Pofadder Dist; 25 mi. van Pofadder op pad na Kakamas, (2819DC), 17 July 1961, Van der Schijff \& Schweickerdt 5716 (PRE!); Kenhardt District. On the road to Nous; 2-3 km N of N14, 920 m, (2819DD), 7 April 2000, Balkwill, McDade \& Lundberg 11797 (J!); Riemvasmaak, $2800 \mathrm{ft},(2820 \mathrm{AD})$, 23 April 1988, Matthews 126 (PRU!); $80 \mathrm{~km}$ vanaf Ariamsvlei op pad na Upington, (2820BC), 26 June 1981, Van Wyk 4478 (PRE!, PRU!); Great Bushmanland; Kalahari; betw. Kakamas \& Bladgrond, (2820C), October 1938, Esterhuysen 1264 (BOL!, PRE!); Gordonia District. Augrabies Waterfall National Park. New part of park, 1 km from one-way split in road in westerly direction (on tourist route), 656 m, (2820CA), 23 August 2005, Steyn 784 (PRE!); Augrabies Falls National Park. Near Ararat, (2820CB), 25 June 2011, Du Plessis 130 (PRE!); Kakamas District: Halfway between

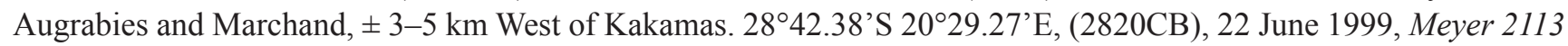
(PRE!); Kenhardt District; 116 km E of Pofadder, 715 m, (2820CD), 5 August 2013, Steyn 1909 (PRE!); Keimoes; nr. Keimoes, (2820DB), 26 June 1950, Theron 821 (PRE!); Kenhardt Div.; Kakamas Veld Reserve, 2100 ft, (2820DC), 10 May 1952, Acocks 16357 (PRE!); Kenhardt Div.; Kakamas, (2820DC), no date, Fuller 5 (PRE!); Kakamas Dist.; 5 mi. 
buite Kakamas op pad na Pofadder, (2820DC), 17 July 1961, Van der Schijff \& Schweickerdt 5694 (PRE!, PRU!); Kenhardt Div.; Kakamas; Letterkop Bot. Res. 'Harde \& Sagte' kamp, (2820DC), 12 July 1946, Wasserfall 1092 (PRE!); Upington, (2821AC), 27 April 1961, Mostert 1308 (PRE!); Upington Div., (2821AC), 8 August 1961, Mostert 1424 (NMB!, PRE!); Upington Div.; karakoelplaas, (2821AC), 10 June 1965, Mostert 1633 (PRE!); Kenhardt District. Dirt road from Upington to Groblershoop via Kleinbegin, 910 m, (2821CB), 2 April 2010, Steyn 1747 (PRE!); Hay Division: Rudesheim, (2822DD), June 1920, Louw KMG 1 (KMG!); Namaqualand District: Aggeneys: Black Mountain Area, 960 m, (2918BA), 1 February 2000, Netnou 56 (PRE!); Namaqualand District: Aggeneys: Black Mountain Area, (2918BA), 2 February 2000, Nkoana 654 (PRE!); Ridge E of Goodhouse turn-off en-route to Klein Pella, 786 m, (2918BA), 23 August 2009, Steyn 1693 (PRE!); Aggeneys District. Ghaamsberg. Plateau on rim of crater NW side \pm $400 \mathrm{~m}$ NE of towers, 1120 m, (2918BB), 31 March 1999, Anderson \& Van Heerden 882 (KMG!); Bushmanland; Aggenys Mountain; west of Pofadder, Soutkloof area WSW of Aggenys Farm, (2918BB), 24 August 1977, Oliver, Tölken \& Venter 51 (PRE!); Namaqualand District, Klein Pella, $6.5 \mathrm{~km}$ NW of Klein Pella on $4 \times 4$ route, (2918BB), 5 July 2013, Steyn 1905 (PRE!); Namaqualand District, Klein Pella, along entrance road at foot of koppie, $654 \mathrm{~m}$, (2918BB), 5 July 2013, Steyn 1907 (PRE!); District Namaqualand, Gamsberg. Top of Gamsberg, on south-eastern part of mountain plateau, 1145 m, (2918BD), 13 October 2010, Sachse 925 (PRE!); Namaqualand District: $32 \mathrm{~km}$ E of Aggeneys on road to Pofadder, 900 m, (2919AA), 2 February 2000, Nkoana 676 (PRE!); Pofadder, Eytees-Boomrivier, T'Goob-se-Berg, 880 m, (2919AA), 9 June 2005, Nkoane 286 (PRE!); Pofadder. Pellaberg East, (2919AA), 1 May 1988, Van Jaarsveld \& Leitch 9747 (NBG!); Pofadder, Boomrivier Farm, (2919AB), 10 June 2005, Nkoane 244 (PRE!); Kenhardt District. Pofadder; 10 km E of Pofadder, (2919AB), 7 August 2011, Steyn, H.M. 1844 (PRE!); Pofadder, 25 km east. Along tar road, (2919BA), 4 May 1988, Dean 487 (J!); Kenhardt District. SE of Pofadder. On road between Nuwedam and Banksvlei, 979 m, (2919BB), 21 August 2005, Steyn 750 (PRE!); Kenhardt District. SE of Pofadder. Between Nuwedam and Banksvlei, 993 m, (2919BD), 21 August 2005, Steyn 747 (PRE!); Bushmanland. Farm Droëgrond, ca. 45 km southwest of Kakamas, 942 m, (2920AA), 9 March 2006, Bester 6614 (KMG!, PRE!); Kenhardt District. Farm: Brypaal, ca. 65 km southwest of Kakamas, 867 m, (2920AB), 10 March 2006, Bester 6668 (PRE!); Kenhardt District. Farm: T'Oubeep, portion A, 898 m, (2920AC), 13 March 2006, Bester 6783 (KMG!, PRE!); Kenhardt District. Farm Sandkolk, 90 km south of Kakamas; ca. 1 km directly south of homestead towards Kenhardt/Pofadder road, 898 m, (2920AD), 11 March 2006, Bester 6687 (KMG!, PRE!); 153 km from Pofadder on road to Kenhardt. (42 km from Kenhardt.), (2920DA), 18 November 1995, Koekemoer 1072 (PRE!); Kenhardt Div.; 6 mi. W of town, (2921AC), 15 May 1961, Schlieben 8840 (M!, NBG!, PRE!, Z!); Kenhardt Div.; on farm $10 \mathrm{~km}$. W of Kenhardt, (2921AC), 10 June 1977, Smook \& Harding 761 (PRE!); Kenhardt Div.; 19 mi. ENE of town, $3000 \mathrm{ft}$, (2921AD), 14 September 1961, Leistner 2321 (KMG!, M!, PRE!); Kenhardt District. Farm Rooiput, between Putsonderwater and Kenhardt, 1004 m, (2921BA), 3 April 2010, Steyn 1756 (PRE!); Kenhardt Div.; Angelierspan 40 mi. from Marydale, (2921DA), 13 May 1946, Story 1150 (PRE!); Niekerkshoop. The Asbestos hills, (2922AD), May 1921, Vermeulen KMG 1532 (KMG!); Griquatown Dist; Niekerks Hope; Blaauwboschputs Farm S of Niekerks Hope, 3000 ft, (2922BD), 20 April 1920, Bryant J90 (PRE!); Hay Div.; Niekerkshoop; top of Jasper Mt. few mi. S of Niekerkshoop, (2922BD), 28 October 1936, Hafström 1151 (PRE!); Prieska, (2922DA), 26 July 1969, Kerfoot K6333 (J!); Prieska; commonage, (2922DA), 12 July 1920, Bryant J74 (PRE!); Prieska Div.; 3 mi. N by W of Prieska slopes, 3450 ft, (2922DA), 13 May 1961, Leistner 2290 (KMG!, M!, PRE!); Prieska Div.; 2 mi. NW of town, (2922DA), 13 May 1961, Schlieben 8767 (M!, PRE!, Z!); Prieska, (2922DA), March 1934, Wilman KMG 3046 (KMG!); Prieska District, $15 \mathrm{~km}$ from Prieska on road from Niekerkshoop, 1073 m, (2922DB), 3 April 2000, Balkwill, McDade 11763 (J!); 5 km from Prieska on Niekerkshoop road, (2922DB), 7 June 1977, Smook \& Harding 689 (PRE!); Prieska District; $4.9 \mathrm{~km} \mathrm{~N}$ of bridge on road from Prieska to Niekerkshoop, 919 m, (2922DB), 3 September 2013, Steyn 1915 (PRE!); Asbestos Mountains, (2923A), July 1894, Marloth 2032 (PRE!); Asbestos Mountains, Kloof, (2923AA), September 1811, Burchell 1654 (K!); Herbert Division, Katlani \& Reads Drift, (2923AB), April 1923, Anderson SAM26923 (SAM in NBG!); Hay Div.; Lanyon Vale, (2923AC), 11 March 1937, Acocks 1971 (KMG!, M!, PRE!); Garies; on track between Buffelsfontein and Doornkraal, 491 m, (3018CA), 22 August 2009, Steyn 1681 (PRE!); Fraserburg Div.; Layton, 4500 ft, (3221BB), 8 August 1965, Shearing 58 (PRE!); Merweville: Fraserburg, Layton, Middlewater/Perdeberg grid, 3000 ft, (3221BB), 20 July 1992, Shearing A71 (NBG!, PRE!); Western Cape: Prince Albert Dist.; $10 \mathrm{~km}$ beyond Prince Albert Road on road to Merweville, (3221DC), 7 December 1976, Venter 1434 (PRE!); Beaufort West Div.; Fraserburg Road, (3221DD), July 1935, Broom TRV 33561 (PRE!); Laingsburg, $3000 \mathrm{ft}$, (3320BB), February 1918, Thode STEU2700 (NBG!); Farm Rondekop, W of Buffels River. SW of Laingsburg. 33¹4'46.7'S 2052'13.4”'E, (3320BB), 21 May 2009, Snijman 2334 (NBG!); Laingsburg Div.; near Ketting Station; to S., 2200 ft, (3321AB), 19 September 1953, Acocks 17139 (PRE!); Koup. Laingsburg, (3321AB), 24 January 1941, Bond 841 (NBG!); Prince Albert District; \pm 15 km W of Prince Albert on dirt road to Gamkapoort Dam, (3321BB), 3 
September 2013, Steyn 1900 (PRE!); Gamka-Poort Nature Reserve, Southern Karoo: Witpoort, northeast section, along track leading south from entrance gate, $1600 \mathrm{ft},(3321 \mathrm{BC}), 2$ November 1982, Cattell \& Cattell 215 (NBG!); Prince Albert District; $\pm 25 \mathrm{~km}$ N of Prince Albert on dirt road to Leeu Gamka, 500 m, (3322AA), 3 September 2012, Steyn 1895 (PRE!); Prince Albert, (3322AB), May 1907, Marloth 4479 (NBG!, PRE!); Prince Albert, Farm Tierberg, Tierberg, N slope, 3308'2.3”S 2216'52.9”'E, (3322AB), 31 August 2006, Roux 4171 (NBG!). Without specific locality: Lichtenstein s.n. (GZU000259883, fragment scan!); Thorne SAM59171 (SAM in NBG!).

6. Acanthopsis disperma Nees in Candolle (1847: 278); Anderson (1864: 36); Clarke (1901: 34); Meyer (1961: 21); Le Roux (2005: 255); Mannheimer et al. (2008: 218), pro parte; Balkwill (2012: 257); Snijman (2013: 163) (Figs. 1, $3 \mathrm{~F}, 9)$

Type:- [SOUTH AFRICA. Northern Cape:] Afr. Austr.: Zwischen Natvoet und Garip. [Annotation in Clarke's handwriting: Between Holgat R. \& Gariep R. alt 1000-1500 feet, Little Namaqualand], (2816D), September 1830, Drège s.n. (lectotype K000394340! designated here; iso-lectotypes BM000810291 scan!, K000394341!, P04426149!, P04426150!, P04426151!, S-G-40 scan!).

Acanthodium dispermum E.Mey. in Drège (1837: 2), nom. nud.

Acanthodium dipsaceum E.Mey. in Drège (1843: 92), nom. nud.

Spiny, acaulescent herb up to $100 \mathrm{~mm}$ tall. Leaves tufted, arranged in a rosette, obovate to broadly lanceolate (30-)40$60(-150) \times 10-20 \mathrm{~mm}$; cotyledons in seedlings reniform (strikingly different from ordinary leaves); leaf margin flat or undulate, spinose, spines fine, up to 2(3) $\mathrm{mm}$ long; with appressed, strigose or spreading hairs; apex rounded to acute; base attenuate; petiole 3-10 $\mathrm{mm}$ long, usually without prominent tufts of long, silky hairs at the base. Inflorescences 1-5 per plant, 20-60(-100) $\mathrm{mm}$ long, (12-)13-15(-20) $\mathrm{mm}$ in diameter, persisting after plant has died. Bracts fanshaped, 15-20 mm long, base 4-5 mm long; middle and upper bracts ending in 5 primary spines, central primary spine always compound (with 2 or 3 pairs of marginal secondary spines), lateral primary spines with 1 or 2 basal and 3-5 marginal secondary spines; spine tips often tinged purple-brown; primary spines usually recurved and secondary spines spreading in fruit; bract base hirsute to pubescent with deflexed to spreading short hairs and some scattered long hairs, with ring of long, silky hairs adaxially at base of spines; spines almost glabrous with margin of rigid, long hairs and sessile/sub-sessile glands, or pubescent to villose (long, silky hairs interspersed with deflexed short hairs and sessile/sub-sessile glands). Bracteoles sickle-shaped, 7-9 mm long, silky hairy. Calyx tips often almost glabrous, with long silky hairs towards base; dorsal sepal ovate, cuspidate, (10-)11(-14) mm long, densely silky hairy, especially adaxially, 7-9-veined from base; ventral sepal ovate, 9-11 mm long, densely silky hairy, especially adaxially, 5-7veined from base; lateral sepals $7-8 \mathrm{~mm}$ long, densely silky hairy on both sides. Flowers blue-purple with white throat; corolla 19-22(-28) × 7-9(-12) mm, tube (5-)6-9(-11) mm long; central lobe longer than wide or equal, slightly constricted at base, truncate to emarginate. Stamens with purple-black anthers, $2 \mathrm{~mm}$ long, filaments 4-5 $\mathrm{mm}$ long, sparsely glandular, hairy towards base. Style with patch or ring of glandular hairs at base. Capsules ovate in face view, flattened, glabrous, shiny, 5-7 × 3-4 mm, 2-seeded. Seeds (3-)5 × $3 \mathrm{~mm}$, covered with long white hygroscopic hairs.

Etymology:-The epithet disperma refers to the two-seeded capsule (1 seed per locule).

Distribution, ecology and phenology:-Acanthopsis disperma is centred in the Gariep Centre of Endemism (Van Wyk \& Smith 2001) and occurs in southern Namibia and the bordering Richtersveld, Northern Cape, South Africa (Fig. 1). It is found in the transitional zone between winter- and summer-rainfall regions (either falling in early winter or late summer) in the Succulent Karoo and Nama-Karoo Biomes (Rutherford \& Westfall 1994, Low \& Rebelo 1996) or partly also in the Desert Biome of Mucina \& Rutherford (2006). The plants prefer weathered granite or quartzite and are found in sandy and gravelly soils on plains and hill slopes at elevations of 65-1200 m with a mean annual rainfall of 20-100 mm per year. Metelerkamp 407 (BOL) noted that the plants are grazed and that the Afrikaans vernacular name volstruisvoet ("ostrich foot") is presumably derived from one tuft (inflorescence) being smaller than the other. Flowering time: mainly April-September.

Conservation status:-Acanthopsis disperma is a widespread and common species, and is therefore classified as Least Concern (L. von Staden, pers. comm. 2014).

Notes:-Acanthopsis disperma is an acaulescent annual herb with thick, dense inflorescences and differs from A. hoffmannseggiana in not having long, viscid glandular hairs on the bracts and with a more westerly distribution, and from A. adamanticola in its non-glaucous appearance with a more easterly distribution. Although the hairiness of leaves and bracts is fairly variable, the plants retain their annual, acaulescent habit. Plants with glabrous or almost glabrous bracts are found in the winter-rainfall areas where rainfall usually coincides with lower temperatures, while 
the form with velvety to villose bracts (hairy bract form) is predominantly associated with the northern and eastern parts of the species' range which falls in the late summer-rainfall part of the Nama-Karoo Biome (warm temperatures in the rainy season) (Steyn \& Condy in press).

Kerfoot 5915 (NBG!) bears the locality "Pilaarsberg, N of Pakhuis Pass". If correct, this would be the only record of Acanthopsis disperma for the Western Cape, and a long way outside the currently accepted distribution range of the species. This specimen is most probably mislabelled as the label also states "heads of dull buff to orange flowers", and it has therefore been excluded. Niven 25 cited by Clarke (1901) from the Groot (Gamtoos) River [probably Gariep River] could not be traced and has also been excluded.
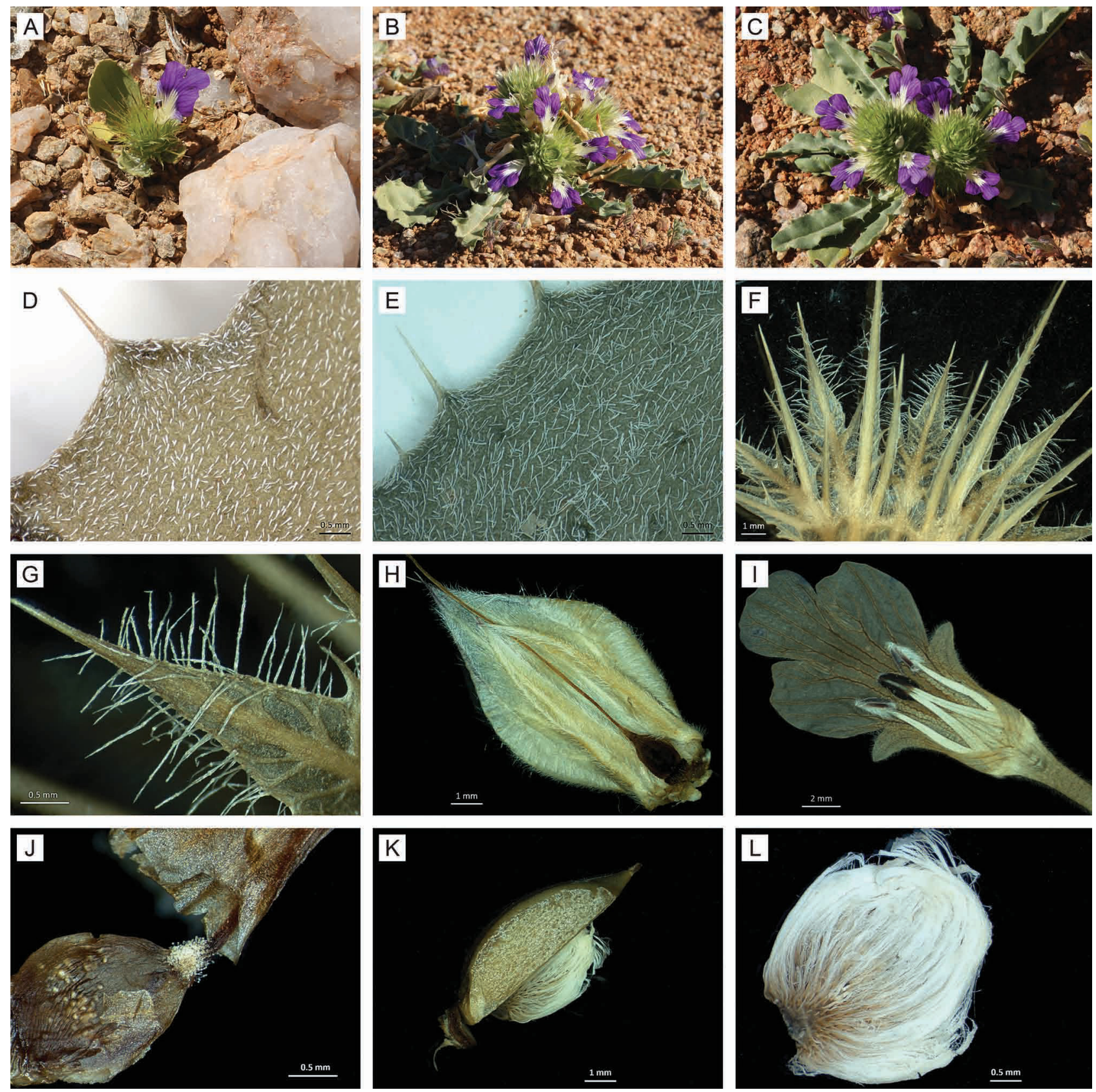

FIGURE 9. Acanthopsis disperma: morphology. A-C. Habit. D \& E. Leaf indumentum. F \& G. Bract. H. Calyx. I. Flower (corolla lobes blue-purple; throat white). J. Glandular hairs at base of style. K. Part of capsule and seed. L. Seed. Vouchers: D = Koekemoer 4183 (PRE), $\mathrm{E}=$ Steyn 1686 (PRE), F, G = Drège s.n (K), H, I = Steyn 1845 (PRE), J = Koekemoer 4187 (PRE), K, L = Van der Westhuizen 236 (PRE). Photographs: M. Koekemoer (A-C).

Acanthodium dispermum E.Mey. var. villosa Schinz (1890: 201) and Blepharis acaulis Lindau (1913: 403) (see Vollesen 2000) were omitted as synonyms of $A$. disperma, as their type specimens could not be traced and verified.

Additional specimens examined:-NAMIBIA. Karas: Aus, Municipal Campsite, rocky outcrop, sandstone, 1611 m, (2616CB), 7 August 2001, Bartsch SB384 (PRE!, WIND!); Aus, 1400 m, (2616CB), 11 January 1910, Dinter 
1136 (SAM in NBG!); Hang hinter dem Wohnhaus d. Farm Plateau bei Aus, 1500 m, (2616CB), 21 May 1954, Kraeusel 853 (M!); In front of homestead of Farm Plateau, LU 38, (2616CB), 8 September 1963, Kraeusel \& Wiss 2013 (WIND!); Farm Plateau, (2616CB), Merxmüller \& Giess 3018 (M!); Auf Quarzit vor Aus in Richtung Helminghausen [Helmeringhausen], (2616CB), 1956, Volk 12818 a (M!); Namib north of Aus, (2616CB), 28 May 1956, Volk 12819 (WIND!); Farm Plateau, locality of succulents on 'Block' plain, (2616CB), 13 April 1953, Walter 2551 (M!, WIND!); Farm Aar, in river, (2616DA), May 1979, Wendt 100 (WIND!); Kuibis, 1350 m, (2616DB), February 1910, Range 828 (SAM in NBG!); $7 \mathrm{~km}$ from Keetmanshoop on road to Goageb, on southern slope of koppie, (2617DD), 10 May 1976, Müller 267 (WIND!); Sandykop (LUS 94) Lehmfläche unterhalb Schwarzkalkrücken mit Aloe pachygaster, (2716AD), 16 September 1972, Merxmüller \& Giess 28479 (M!); Road from Aus to Rosh Pinah, just past Witputz, 1040 m, (2716DA), 2 August 2002, Maggs GM2012 (PRE!, WIND!); Farm Kolke: LU 84; quartzite koppie on mountain slope near homestead, in coarse rocks, (2716DB), 11 June 1976, Giess \& Müller 14335 (M!, WIND!); On the farm Kolke, NE of Rosh Pinah, 1252 m, (2716DB), 16 August 2012, Koekemoer 4315 (PRE!); Diamond Area no 1; Rosh Pinah; $6 \mathrm{~km} \mathrm{~W}$ at entrance gate to Diamond Area, (2716DC), 1 September 1989, Van Wyk 8938 (PRE!, PRU!); Richtersveld National Park. Rosh Pinah, W van vliegveld, (2716DD), 1 September 1989, Zietsman 1828 (NMB!, WIND!); Wegdraai, Hottentots Plateau, 799 m, (2717CB), 7 May 2002, Helary \& Batault 210 (WIND!); Huns Mountains, 8.5 km upstream of Boomriver mouth, (2717CC), 17 June 1993, Ströhbach 477 (WIND!); Karasburg District: Fish River Canyon, (2717DA), 3 August 1979, Owen-Smith 1241 (WIND!); Fischfluss-Canyon, (2717DA), 29 March 1953, Walter 2288 (M!); Farm Holoogberg: KEE 107. Coarse sand plain with Stipagrostis brevifolia stands, (2717DB), 17 June 1976, Giess \& Müller 14443 (WIND!); Warmbad Dist.; lower Fish River; Kanibis-Aiais, 800 m, (2717DC), August 1909, Marloth 4801 (PRE!); Klein Karas, (2718CA), October 1913, Dinter 3225 (SAM in NBG!); Klein Karas, (2718CA), 3 August 1923, Dinter 4828 (PRE!, SAM in NBG!); Great Namaqualand; Klein Karas, (2718CA), 9 April 1931, Ortendahl 48 (PRE!); 20 mil. S of Grunau, Kälkgeroll, Fläche, (2718CC), 14 May 1963, Bleissner 252 (M!); Sperrgebiet 1-border; $5 \mathrm{~km}$ north of Orange River at Sendelingsdrift, on mountain slope, common, (2816BB), 12 June 1976, Giess \& Müller 14372 (M!, WIND!); Loreley Copper Mine, very weathered schist, (2816BB), 22 February 1963, Giess, Volk \& Bleissner 5415 (M!, WIND!); ca. $40 \mathrm{~km}$ from Aussenkehr on road to Sendelingsdrif, (2817AA), 3 July 2013, Steyn 1904 (PRE!); Southern Namibia: Orange River Valley; 17.5km below Fish/Orange confluence, 65 m, (2817AA), 14 September 1988, Ward 10330 (PRE!, WIND!); Between Sendelingsdrift and Rosh Pinah. On the floodplain at the foot of the mountain, $258 \mathrm{~m}$, (2817AB), 15 August 2012, Koekemoer 4314 (PRE!); $6 \mathrm{~km}$ north along Ai-Ais $4 \times 4$ Trail from road C13 (Rosh Pinah-Noordoewer) on Orange River, 180 m, (2817AD), 17 October 2005, Kolberg \& Tholkes HK1721 (WIND!); Slopes between Modder Drift and Sjambok River, (2817CB), September 1931, Pillans 6456 (BOL!); Warmbad Dist.; Norachas WAR 14 Farm, (2818AA), 14 May 1963, Giess, Volk \& Bleissner 6901 (M!, PRE!, WIND!); Warmbad Dist.; Haib River, 600 m, (2818AC), June 1929, Marloth 13243 (PRE!); Warmbad Dist.; Witputs WAR 258 Farm, (2818CA), 15 May 1963, Giess, Volk \& Bleissner 6949 (M!, PRE!, WIND!). SOUTH AFRICA. Northern Cape: Richtersveld National Park, (2816BB), 6 July 1993, Bezuidenhout 566 (NMB!); Sendelingsdrif, (2816BB), 25 August 1982, Metelerkamp 407 (BOL!); Sides of Kodas River, (2816BB), October 1926, Pillans 5492 (BOL!); Richtersveld National Park. Between Sendelingsdrif and Potjiespram, (2816BB), 10 July 1993, Van Rooyen 2279 (PRU!); Richtersveld. Koeboes, (2816BD), 29 September 1930, Herre STEU12499 (NBG!); Richtersveld; Noemees, (2816BD), 6 October 1991, Koekemoer 923 (PRE!); Richtersveld National Park; hill near Numees mine, 394 m, (2816BD), 13 July 2011, Koekemoer 4187 (PRE!); Richtersveld. At the foot of Cornellskop, 125 m, (2816BD), 1 September 2012, Koekemoer 4364 (PRE!); Richtersveld National Park. Noemeesberg, (2816BD), 14 September 1985, Zietsman \& Zietsman 750 (NMB!); Richtersveld National Park. Noemeesberg, (2816DB), 1 October 1991, Zietsman 2064 (NMB!); Namaqualand District. Richtersveld National Park. Between Potjiespram and De Hoop, (2817AA), 11 September 2010, Steyn 1811 (PRE!); Richtersveld. Maerpoort, (2817AA), 7 August 1991, Van Jaarsveld 11762 (PRE!); Richtersveld National Park. De Hoop, (2817AA), 1 October 1991, Zietsman 2130 (NMB!, PRU!);

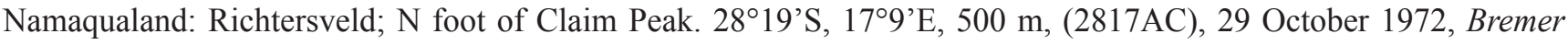
417 (PRE!); Richtersveld. Helskloof. Noisabis, (2817AC), 3 October1930, Herre STEU13095 (NBG!); Richtersveld; in the Zebra Kloof; just NE of Rosyntjieberg, (2817AC), 9 October 1991, Germishuizen 5570 (PRE!); Richtersveld National Park. Near Hakiesdoring Camp on quartzite ridge, 327 m, (2817AC), 11 July 2011, Koekemoer 4183 (PRE!); Namaqualand District. Richtersveld National Park. Between Gannakouriep Camp and Helskloof turn-off, (2817AC), 13 September 2010, Steyn 1814 (PRE!);West foot of Rosyntjieberg. Stony plateau, 500 m, (2817AC), 30 August 1977, Thompson \& Le Roux 183 (NBG!, PRE!); Port Nolloth Dist.; Namakwaland, Richtersveld 12 myl S van Grasdrif, 1800 ft, (2817AC), 17 May 1972, Van der Westhuizen 236 (PRE!); Richtersveld National Park. At Kokerboomkloof camping site, (2817AC), 30 August 2010, Zietsman \& Zietsman 4754 (NMB!); Richtersveld. Tatasberge, (2817AD), 2 October 1930, Herre STEU13096 (NBG!); Namaqualand District. Richtersveld, Sunvalley camp site, 551 m, (2817CB), 8 
August 2011, Steyn 1845 (PRE!); Namaqualand District. Richtersveld, between Sunvalley turn-off and camp site, 520 m, (2817CB), 8 August 2011, Steyn 1852 (PRE!); Namaqualand District. Richtersveld, track to Rosynebos N of Basterfontein, 445 m, (2817CB), 9 August 2011, Steyn 1855 (PRE!); Vioolsdrif. Mountain W of the confluence of Stinkfonteinrivier and Orange River, 636 m, (2817CB), 14 April 1986, Van Jaarsveld, Forrester \& Jacobs 8437 (NBG!); 13 mi. E of Stinkfontein (Eksteenfontein), $1800 \mathrm{ft}$, (2817CD), 12 May 1969, Leistner 3380 (PRE!); S of Vioolsdrif at the Swartkop mine, near the farmhouse, 597 m, (2817DC), 21 August 2012, Koekemoer 4329 (PRE!); Vioolsdrift; just outside town, (2817DC), 15 August 1967, Van der Schijff 8177 (PRE!, PRU!); 16 km south of Vioolsdrif, (2817DC), 2 June 1976, Wisura 3629 (NBG!); Between Henkries and Goodhouse turn-off on road between Concordia and Pella, 490 m, (2818CC), 23 August 2009, Steyn 1686 (PRE!); Namakwaland District. 69.1 km from P.O. Concordia. On road to Goodhouse, 590 m, (2918AA), 4 April 2000, Balkwill, McDade \& Lundberg 11780 (J!). Without legible or specific locality: Klaassen, Bartsch \& Loots EK1205 (PRE!, WIND!); Range 692 (SAM in NBG!); Wyley s.n. (TCD!).

\section{Acanthopsis dispermoides H.M.Steyn, sp. nov. (Figs. 1, 3G, 10)}

Acanthopsis dispermoides can be distinguished from A. disperma by being a biennial or perennial ( $v s$. an annual herb), with subsessile (petiole $2 \mathrm{~mm}$ long) to sessile leaves (vs. petiolated leaves; petiole 3-10 $\mathrm{mm}$ long) and a distribution which is restricted to the Western Cape (vs. Namibia and Northern Cape, South Africa), and from A. hoffmannseggiana, its closest neighbour (and probably relative) occurring to the north of the Swartberg Mountains in the Great Karoo, by the much shorter (sub-sessile; $<0.2 \mathrm{~mm}$ long) glandular hairs on the bracts (vs. 0.2-0.3(-0.4) $\mathrm{mm}$ long), the strigose to appressed leaf indumentum (vs. spreading glandular hairs) and the narrower $((8-) 10-12 \mathrm{~mm}$ in diameter) inflorescences (vs. (12-)15-18(-20) $\mathrm{mm}$ in diameter).

Type:-SOUTH AFRICA. [Western Cape]: Little Karoo. Eastern foothills of Warmwaterberg. Lot 2, near spring, 600 m, (3320DD), 21 August 1971, Boucher 1560 (PRE 40576) (holotype PRE0129553-0!; isotype NBG0274662-0!).

A. disperma sensu Vlok \& Schutte-Vlok (2010: 187 fig.), misapplied name, non Nees.

Biennial or perennial acaulescent herb, rarely a subshrub with reduced branching, up to 100(-200) $\mathrm{mm}$ high. Leaves tufted, oblanceolate to lanceolate, 40-80(-100) × 8-12(-18) $\mathrm{mm}$; margin undulate, irregular shallowly dentate spinose, spines fine up to 2(3) $\mathrm{mm}$ long; hairs appressed to strigose with isolated sessile or subsessile glands; base attenuate; sessile to subsessile, if petiole present (up to $2 \mathrm{~mm}$ long). Inflorescences 25-60(-70) $\mathrm{mm}$ long, (8-)10-12 $\mathrm{mm}$ in diameter. Bracts obovate to fan-shaped, 13-15(-20) $\mathrm{mm}$ long, base 5-8 $\mathrm{mm}$ long; middle and upper bracts ending in 5 primary spines; central primary spine always compound (with 2 or 3(4) pairs of marginal secondary spines), lateral spines with 2 basal secondary spines and 3(4) marginal secondary spines; spine tips often tinged maroon; primary spines usually recurved and secondary spines spreading in fruit; bract base hirsute to pubescent with deflexed to spreading short hairs, spines usually villose (long silky hairs interspersed with deflexed to spreading short hairs and short, subsessile glandular hairs, the latter $<0.2 \mathrm{~mm}$ long). Bracteoles lanceolate, 7-9(-10) $\mathrm{mm}$ long, silky hairy. Calyx tips often tinged maroon; dorsal sepal ovate, apiculate to cuspidate, 10-12(-14) mm long, densely silky hairy, especially adaxially, 5-7-veined from base; ventral sepal ovate, $8-11 \mathrm{~mm}$ long, densely silky hairy, especially adaxially, 5-7-veined from base; lateral sepals 7-9 mm long, densely silky hairy. Flowers blue-purple with white throat, corolla 23-27 × 10-12 mm, tube 8-12 mm long, central lobe wider than long or equal, slightly constricted at base, truncate to emarginated. Stamens with anthers purple-black, $2 \mathrm{~mm}$ long; filaments $4-5 \mathrm{~mm}$ long, sparsely glandular, hairy towards base. Style with patch of glandular hairs at base. Capsules ovate in face view, flattened, glabrous, shiny, 6-7 × 3-4 mm, 2-seeded. Seeds $4 \times 3 \mathrm{~mm}$, covered with long white hygroscopic hairs.

Etymology:-The specific epithet, dispermoides (the Latin meaning "resembling disperma") refers to the fact that the taxon were hitherto misidentified as $A$. disperma as opposed to the probably more closely related $A$. hoffmannseggiana, due to the absence of long, viscid glandular hairs on the bracts.

Distribution, ecology and phenology:-Known from only five populations in the western Little Karoo between Wittepoort in the north to Warmwaterberg in the south (Fig. 1), a range falling within the Little Karoo Centre of Endemism (Van Wyk \& Smith 2001). Acanthopsis dispermoides grows on mountain slopes and rocky ridges (between $370-600 \mathrm{~m}$ ) in a region receiving an average of $200-300 \mathrm{~mm}$ of rain per year. It is often found in the transition zone between the Fynbos and Succulent Karoo Biomes (Rutherford \& Westfall 1994, Low \& Rebelo 1996, Mucina \& Rutherford 2006) on sandstone or shale. Vlok \& Schutte-Vlok (2010) recorded that this Little Karoo species can be abundant in clayey soils in Gwarrieveld (Thicket Biome), Ranteveld and Apronveld (Succulent Karoo Biome). Flowering time: June-October. 

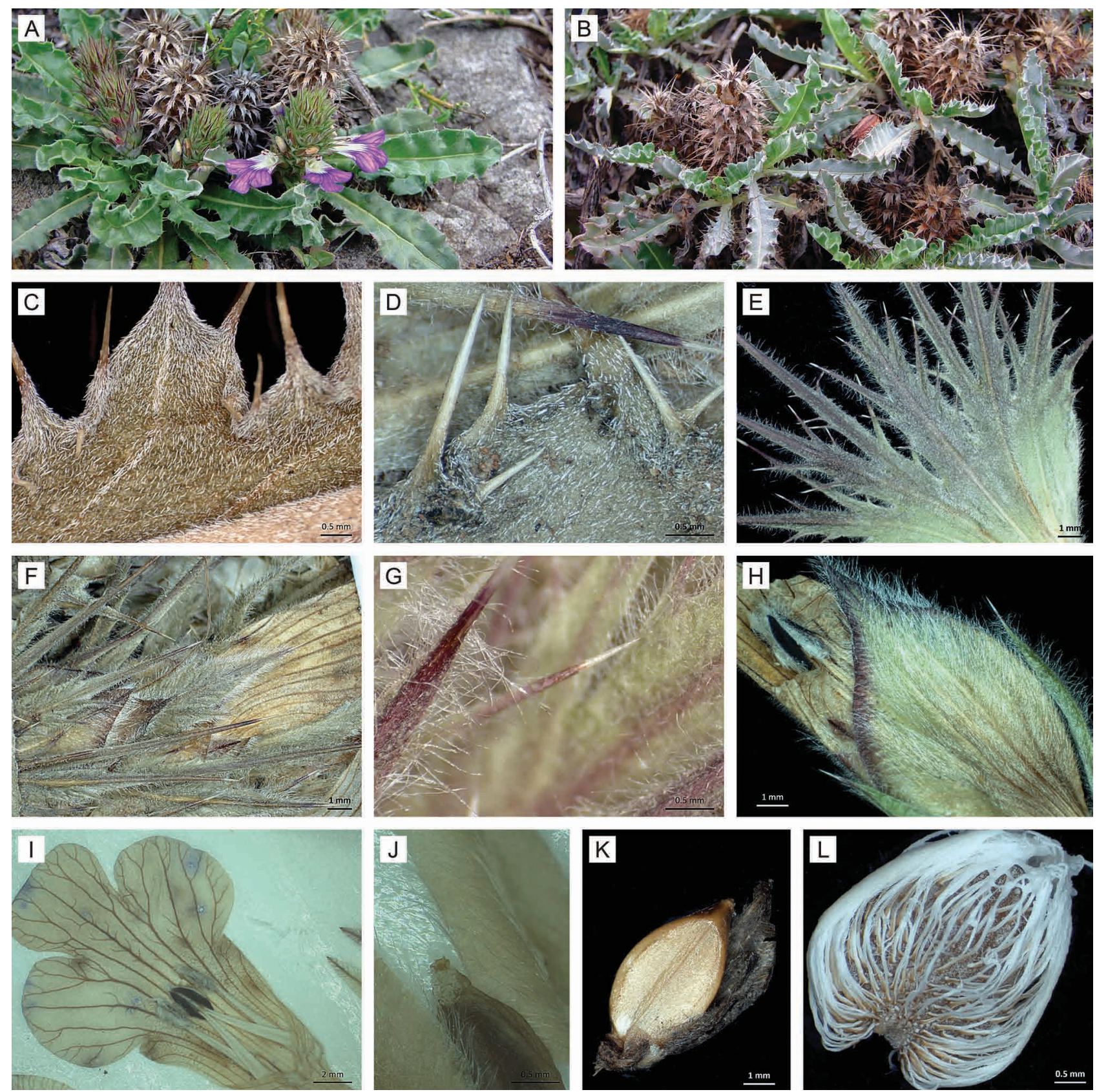

FIGURE 10. Acanthopsis dispermoides: morphology. A \& B. Habit. C \& D. Leaf indumentum. E-G. Bract. H. Calyx. I. Flower (corolla lobes blue-purple; throat white). J. Glandular hairs at base of style. K. Capsule. L. Seed. Vouchers: C, E, G-J = Steyn 1912 (PRE), D, F, $\mathrm{K}, \mathrm{L}=$ Boucher PRE 40576 (PRE).

Conservation status:-Acanthopsis dispermoides has a restricted range (Extent of Occurrence $716 \mathrm{~km}^{2}$ ), and occurs in an area that is severely overgrazed in places. It is however locally abundant, resilient to disturbance and appears to thrive under conditions of overgrazing, and is therefore unlikely to be threatened (J. Vlok, pers. com. 2015), and classified as Least Concern (IUCN 2001) (L. von Staden, pers. com. 2015).

Notes:-Based on the distribution and the absence of long, viscid glandular hairs on the bracts, Viviers, Vlok \& Bond 272 (PRE!) from Anysberg Mountain, is included in Acanthopsis dispermoides although the leaf indumentum includes spreading glandular hairs. Further fieldwork is needed to clarify the relationships between the two Western Cape species ( $A$. dispermoides and $A$. hoffmannseggiana) and to determine the full distribution range and the abundance of Acanthopsis dispermoides. As more taxonomic evidence becomes available in future, it is quite possible that $A$. dispermoides would rather be regarded as an infraspecific taxon within $A$. hoffmannseggiana (see Notes under A. hoffmannseggiana). For the moment, however, A. dispermoides is recognized at species level to highlight its morphological distinctness (mainly in bract and leaf indumentum and inflorescence diameter), and its geographical confinement to the Little Karoo, the most southerly distribution for a member of the genus. 
Additional specimens examined:-SOUTH AFRICA. Western Cape: Wittepoort, (3320BD), 23 September 1941, Barker 1507 (NBG!); District Ladismith: Touwsberg; NW side of Touwsberg; Foothills of farm Kleinfontein 123, S3332’31.5”, E2055’36”, 450 m, (3320DB), 6 October 1993, Bredenkamp 830 (PRE!); Touwsberg; Farm Kleinfontein NW side of mountain, (3320DB), 6 October 1993, Smook 8679 (PRE!); Warmwaterberg, (3320DD), 11 July 1945, Compton 20531 (NBG!); Swellendam District. Warmwaterberg, at back of reception, along hiking trail, 510 m, (3320DD), 16 August 2013, Steyn 1912 (PRE!); Swellendam Div.; Warmwaterberg; ridge above Warmwaterberg hotel 18 mi. from Barrydale on rd. to Ladismith, 3000 ft, (3320DD), 21 June 1963, Taylor 4874 (PRE!, NBG!); Klein Karoo. Pad na Kromkloof by Droogedam, 370 m, (3321CA), 16 June 1993, Bohnen 9352 (NBG!).

Without precise locality: Fourie STE31220 (NBG!).

\section{Acknowledgements}

The authors would like to thank colleagues, especially Paul Herman, for helpful comments and suggestions; John and Sandie Burrows, Ronell Klopper and Marianne le Roux for studying type material at K (Kew) and B (Berlin); the directors or curators who supplied high quality scans or specimens on loan (BOL, BM, K, M, NBG, P, TCD and WIND); Pieter van Wyk, Nick Helme, Lize von Staden, Marinda Koekemoer and Pieter Bester for collecting herbarium vouchers and supplying images; Coleen Mannheimer for images of Namibian plants; the owners of Warmwaterberg Spa near Barrydale for permission to collect specimens on their property; Caroline Mudau and Paul Herman for help in the lab; Ilva Rogers for georeferencing all the specimens in SANBI's database; Dr Hugh Glen and Dr Otto Leistner for help with Latin translations; Jan Vlok for field observations; Lize von Staden and Sonja Loots for assessing the conservation status of the various species; Gillian Condy for the line drawings and Elizma Fouché for preparing the photo plates. We appreciate the constructive and useful comments of an anomymous reviewer. Our grateful thanks to CapeNature as well as the Department of Tourism, Environment and Conservation: Northern Cape, for plant collecting permits, and the Botanical Education Trust and National Research Foundation for financial support.

\section{References}

Anderson, T. (1864) An enumeration of the species of Acanthaceae from the continent and the adjacent islands. Journal of the Proceedings of the Linnaean Society, Botany 7: 13-54.

Balkwill, K. (2012) Acanthopsis. In: Manning, J.C. \& Goldblatt, P. (Eds.) Plants of the Greater Cape Floristic Region 1: the Core Cape flora, Strelitzia 29. South African National Biodiversity Institute, Pretoria, pp. 1-257.

Beentje, H. (2010) The Kew plant glossary, an illustrated dictionary of plant terms. Kew Publishing, Kew, 160 pp.

Candolle, A.P. de (1847) Prodromus systematis naturalis regni vegetabilis 11. Treuttel \& Würtz, Paris, 736 pp.

Clarke, C.B. (1901) Acanthaceae. In: Thiselton-Dyer, W.T. (Ed.) Flora capensis 5, 1. Lovell Reeve \& Co., London, pp. 1-92. http://dx.doi.org/10.5962/bhl.title.821

Delile, A.R. (1812) Description de l'Egypte, histoire naturelle 2. Imprimerie Impériale, Paris, pp. 1- 241, t. 33. http://dx.doi.org/10.5962/bhl.title.15786

Desmet, P. (2013) Gamsberg Zinc Project: vegetation baseline and impact assessment report, Draft 5. Report for ERM Southern Africa on behalf of Black Mountain Mining (Pty) Ltd/Vedanta Zinc International, 100 pp.

Drège, J.F. (1837) Catalogus plantarum exsiccatarum Africae australioris quas emturis offert. Regiomonti Borussorum, Greek, 32 pp.

Drège, J.F. (1843) Zwei Pflanzengeographische Documente, nebst einer Einleitung von Dr. E. Meyer. Leipzig, Regensburg, 230 pp. http://dx.doi.org/10.5962/bhl.title.87612

Edwards, D. \& Leistner, O.A. (1971) A degree reference system for citing biological records in southern Africa. Mitteilungen der Botanischen Staatssammlung München 10: 501-509.

Giess, J.W.H. (1971) A preliminary vegetation map of South West Africa. Dinteria 4: 5-144.

Harvey, W.H. (1842) Acanthopsis. In: Hooker, W.J. (Ed.) London Journal of Botany 1. Hippolyte Baillière, London, pp. 1-28.

Herbarium Berolinense (2015) Virtual Herbarium. Available from: http://ww2.bgbm.org/herbarium/ (accessed 24 June 2015)

Holmgren, P.K., Holmgren, N.H. \& Barnett, L.C. (1990) Index herbariorum, Part I. The herbaria of the world, 8th ed. Regnum Vegetabile Vol. 120. The New York Botanical Garden, Bronx, New York, 704 pp.

IUCN (2001) IUCN red list categories and criteria, Version 3.1. IUCN Species Survival Commission, Gland, Switzerland and Cambridge $\mathrm{UK}, \mathrm{iv}+32 \mathrm{pp}$. 
JSTOR (2015) JSTOR Global Plants. Available from: http://plants.jstor.org/search?asf (accessed 24 June 2015)

Jussieu, A.L. de (1789) Genera plantarum secundum ordinares naturales disposita. Publisher unknown, Paris, 499 pp.

Kew Herbarium (2015) Kew Herbarium Catalogue. Available from: http://kew.org/herbcat (accessed 24 June 2015)

Le Roux, A. (2005) Namakwaland. Veldblomgids van Suid-Afrika 1. Botaniese Vereniging van Suid-Afrika, Kaapstad, 336 pp.

Lindau, G. (1913) Blepharis. In: Engler, A. (Ed.) Botanische Jahrbücher für Systematik, Pflanzengeschichte und Pflanzengeographie 49. Verlag von Wilhelm Engelmann, Leipzig, pp. 403-404.

Linnaeus, C. (1753) Species Plantarum. Salvius, Stockholm, 1200 pp. http://dx.doi.org/10.5962/bhl.title.669

Linnaeus, C. (filius) (1782) Supplementum plantarum. Impensis Orphanotrophei, Brunsvigae, 502 pp.

Low, A.B. \& Rebelo, A.G. (Eds.) (1996) Vegetation of South Africa, Lesotho and Swaziland. Department of Environmental Affairs \& Tourism, Pretoria, 85 pp.

Mannheimer, C., Maggs-Kolling, G., Kolberg, H. \& Rugheimer, S. (2008) Wildflowers of the southern Namib. Macmillan Namibia, Windhoek, $292 \mathrm{pp}$.

McDade, L.A., Daniel, T.F., Kiel, C.A. \& Vollesen, K. (2005) Phylogenetic relationships among Acantheae (Acanthaceae): major lineages present contrasting patterns of molecular evolution and morphological differentiation. Systematic Botany 30: 834-862. http://dx.doi.org/10.1600/036364405775097734

McNeill, J., Barrie, F.R., Buck, W.R., Demoulin, V., Greuter, W. Hawksworth, D.L., Herendeen, P.S., Knapp, S., Marhold, K., Prado, J., Prud'homme van Reine, W.F., Smith, G.F., Wiersema, J.H. \& Turland, N.J. (2012) International Code of Nomenclature for Algae, Fungi, and Plants (Melbourne Code) Regnum Vegetabile 154. Koeltz Scientific Books, Königstein, 240 pp.

Mendelsohn, J., Jarvis, A., Roberts, C. \& Robertson, T. (2002) Atlas of Namibia. A portrait of the land and its people. David Philip, Cape Town, 200 pp.

Meyer, P.G. (1961) Die Acanthaceae und Euphorbiaceae Südwestafrikas. Fotodruck GmbH, München, 151 pp.

Mucina, L. \& Rutherford, M.C. (Eds.) (2006) The vegetation of South Africa, Lesotho and Swaziland. Strelitzia 19. South African National Biodiversity Institute, Pretoria, $807 \mathrm{pp}$.

National History Museum Herbarium (2015) National History Museum Herbarium Data Portal: Specimens. Available from: http://www. nhm.ac.uk/research-curation/scientific-resources/collections/botanical-collections/botany-specimen-database/ (accessed 24 June 2015)

Paris Herbarium (2015) Paris Herbarium MNHN collections. Available from: http://colhelper.mnhn.fr/ (accessed 24 June 2015)

Raimondo, D., Von Staden, L., Foden, W., Victor, J.E., Helme, N.A., Turner, R.C., Kamundi, D.A. \& Manyama, P.A. (Eds.) (2009) Red List of South African plants. Strelitzia 25. South African National Biodiversity Institute, Pretoria, 668 pp.

Rutherford, M.C. \& Westfall, R.H. (1994) Biomes of southern Africa: an objective categorization. Memoir 63. National Botanical Institute, Pretoria, $94 \mathrm{pp}$.

Schinz, H. (1890) Beiträge zur Kenntnis der Flora von Deutsch-Südwest-Afrika und der angrenzenden Gebiete. Verhandlungen des Botanischen Vereins für die Provinz Brandenbrug und die Angrenzenden Länder 31: 179-230.

Schmid, R. (1982) Decriptors used to indicate abundance and frequency in ecology and systematics. Taxon 31: 89-94.

Snijman, D.A. (2013) Acanthopis. In: Plants of the Greater Cape Floristic Region 2: the Extra Cape Flora. Strelitzia 30. South African National Biodiversity Institute, Pretoria, pp. 1-163.

Steyn, H.M. \& Condy, G. (in press) Acanthopsis disperma Acanthaceae. Flowering Plants of Africa.

Swedish Museum of Natural History Herbarium (2015) Swedish Museum of Natural History Herbarium Naturhistoriska riksmuseet. Available from: http://www.nrm.se/english.16_en.html (accessed 24 June 2015)

Van Wyk, A.E. \& Smith, G.F. (2001) Regions of floristic endemism in southern Africa: a review with emphasis on succulents. Umdaus Press, Pretoria, 160 pp.

Vlok, J. \& Schutte-Vlok, A.L. (2010) Plants of the Klein Karoo. Umdaus Press, Pretoria, 568 pp.

Vollesen, K. (2000) Blepharis, a taxonomic revision. Kew, London, 342 pp.

Welman, W.G. (2003) Acanthopsis. In: Germishuizen, G. \& Meyer, N.L. (Eds.) Plants of southern Africa: an annotated checklist. Strelitzia 14. National Botanical Institute, Pretoria, p. 92.

Williamson, G. (2000) Richtersveld, the enchanted wilderness. Umdaus Press, Pretoria, $250 \mathrm{pp}$.

Zürich Herbaria (2015) Zürich Herbaria Database. Available from: http://www.herbarien.uzh.ch/static/database/ (accessed February 2015) 